\title{
Radiative forcing from tropospheric ozone calculated with a unified chemistry-climate model
}

\section{Citation}

Mickley, L. J., P. P. Murti, D. J. Jacob, J. A. Logan, D. M. Koch, and D. Rind. 1999. “Radiative Forcing from Tropospheric Ozone Calculated with a Unified Chemistry-Climate Model." Journal of Geophysical Research 104, issue D23: 30153-30172.

\section{Published Version}

doi:10.1029/1999JD900439

\section{Permanent link}

http://nrs.harvard.edu/urn-3:HUL.InstRepos:14117809

\section{Terms of Use}

This article was downloaded from Harvard University's DASH repository, and is made available under the terms and conditions applicable to Other Posted Material, as set forth at http:// nrs.harvard.edu/urn-3:HUL.InstRepos:dash.current.terms-of-use\#LAA

\section{Share Your Story}

The Harvard community has made this article openly available.

Please share how this access benefits you. Submit a story.

\section{Accessibility}




\title{
Radiative forcing from tropospheric ozone calculated with a unified chemistry-climate model
}

\author{
L. J. Mickley, P. P. Murti, D. J. Jacob, and J. A. Logan \\ Department of Earth and Planetary Sciences and Division of Engineering and Applied Sciences \\ Harvard University Cambridge, Massachusetts \\ D. M. Koch and D. Rind \\ Goddard Institute for Space Studies, New York
}

\begin{abstract}
We have developed a global model for the study of chemistry-climate interactions by incorporating a detailed simulation of tropospheric ozone- $\mathrm{NO}_{x^{-}}$ hydrocarbon chemistry within a general circulation model (GCM). We present a first application of the model to the calculation of radiative forcing from tropospheric ozone since preindustrial times. Longwave and shortwave radiation fluxes are computed every 5 hours in the GCM using the locally simulated ozone fields. In this manner, the model resolves synoptic-scale correlations between ozone and meteorological variables. A simulation for present-day conditions is compared to a preindustrial atmosphere ( 1800 A.D.) with no fossil fuel combustion, $10 \%$ of present-day biomass burning, and $0.7 \mathrm{ppm}$ methane. The two simulations use the same meteorological fields; the radiative forcing does not feed back into the GCM. The model reproduces well the observed distributions of ozone and its precursors in the present-day atmosphere. Increases in ozone since preindustrial times are $20-200 \%$ depending on region and season. The global mean, instantaneous radiative forcing from anthropogenic ozone is $0.44 \mathrm{~W} \mathrm{~m}^{2}$ ( 0.35 longwave, 0.09 shortwave). The model reveals large shortwave forcings $\left(0.3-0.7 \mathrm{~W} \mathrm{~m}^{2}\right)$ over polar regions in summer. The total forcing is greater than $1.0 \mathrm{~W} \mathrm{~m} \mathrm{~m}^{2}$ over large areas, including the Arctic, during Northern Hemisphere summer. The normalized radiative forcing per

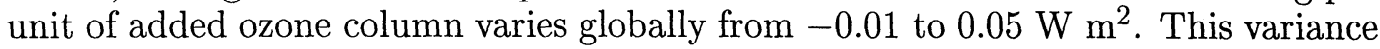
can be explained in large part by the temperature difference between the surface and the tropopause; clouds are an additional factor, particularly at low latitudes. An off-line radiative calculation using the same ozone fields but averaged monthly shows nearly identical forcings, with differences less than $\pm 2 \%$ over most of the Earth. The similarity between the off-line and on-line simulations suggests that the common use of off-line ozone fields is acceptable in radiative forcing calculations. Addition of the direct forcings from anthropogenic sulfate aerosol and tropospheric ozone computed with the same GCM shows compensating effects, with sulfate dominating at northern midlatitudes and ozone usually dominating elsewhere.
\end{abstract}

\section{Introduction}

Ozone in the troposphere is a significant greenhouse gas due to its absorption in the infrared, visible, and ultraviolet spectral regions [Wang et al., 1980; Lacis et al., 1990]. There is observational evidence that troposphcric ozone has increased several-fold since preindustrial times, at least at northern midlatitudes [Staehelin, 1994; Marenco et al., 1994]. Model studies have linked increasing emissions of ozone precursor gases$\mathrm{NO}_{x}\left(\mathrm{NO}+\mathrm{NO}_{2}\right), \mathrm{CO}$, and hydrocarbons-to the in-

Copyright 1999 by the American Geophysical Union.

Paper number 1999JD900439.

0148-0227/99/1999JD900439\$09.00 creasing burden of ozone in the troposphere [Crutzen and Zimmermann, 1991; Levy et al., 1997; Wang and Jacob, 1998]. Despite progress in our understanding of the human influence on troposphcric ozonc, estimates of the global mean radiative forcing duc to ozonc added sincc prcindustrial times range widely, from 0.2 to 0.6 $\mathrm{W} \mathrm{m}{ }^{-2}$ [Houghton et al., 1995]. A key reason for the wide range of estimates is that, unlike most other greenhouse gases, ozone has a short chemical lifetime (weeks), resulting in an inhomogeneous distribution that is difficult to map out with observations or to model. Accurate knowledge of the change of ozone in thrce dimensions, however, is essential to the calculation of the radiative forcing of anthropogenic ozone [Lacis et al., 1990; Hansen et al., 1997; Haywood et al., 1998]. 
With limited ozone observations available, especially from the preindustrial era [Marenco et al., 1994], most radiative forcing studies have relied on models. Twodimensional models [e.g., Hauglustaine et al., 1994; Forster et al., 1996] have tended to overestimate ozone abundances, since $\mathrm{NO}_{x}$ emissions are artificially diluted, increasing the ozone production efficiency [Liu et al., 1987; Kanakidou and Crutzen, 1993]. While threedimensional models can better simulate the meridional variations of ozone, they make heavy demands on computer time. To deal with these demands, previous studies have so far employed a simple $\mathrm{NO}_{x}-\mathrm{CH}_{4}$-CO chemistry [Chalita et al., 1996; Roelofs et al., 1997] and/or have applied monthly mean ozone distributions, calculated off-line, into the radiative transfer code [Chalita et al., 1996; van Dorland et al., 1997; Berntsen et al., 1997; Haywood et al., 1998; Brasseur et al., 1998; Stevenson et al., 1998]. Other studies have inferred seasonally averaged anthropogenic trends in ozone from presentday observations of tropospheric ozone [Portmann et al., 1997; Kiehl et al., 1999]. A simple $\mathrm{NO}_{x}-\mathrm{CH}_{4}-\mathrm{CO}$ chemistry neglects the important contribution of nonmethane hycarbons (NMHCs), in particular isoprene, to ozone production [Wang et al., 1998a; Horowitz et al., 1998]. Using monthly or seasonally averaged ozone distributions in radiative calculations ignores the short-term correlations between ozone and meteorological variables such as clouds and temperature [e.g., Pickering et al., 1992; Sillman and Samson, 1995].

To improve estimates of the radiative forcing from anthropogenic ozone since preindustrial times, we have implemented a detailed on-line simulation of tropospheric ozone- $\mathrm{NO}_{x}$-NMHCs chemistry in a general circulation model developed at the Goddard Institute for Space Studies, the GISS GCM $2^{\prime}$ [Rind and Lerner, 1996]. Radiative forcing is calculated every 5 hours in the GCM, using the locally simulated ozone fields. In this manner, we hope to resolve the synoptic-scale correlations of ozone with other radiative variables, in particular temperature and clouds. The radiative forcing calculations do not for now feed back into the GCM climate, so that the preindustrial and present-day simulations use the same meteorological fields. An on-line simulation of radiative forcing from anthropogenic sulfate using the same GCM is presented by Koch et al. [1999]. We examinc here the sum of these two forcings.

In section 2 of this paper we describe the coupled GCM-chemistry model. In section 3 we compare the calculated distributions of ozone and related species to observations in the present-day atmosphere, and in section 4 we discuss output from the preindustrial simulation. In section 5 , we present and discuss results from the radiative forcing calculations. Our conclusions are in section 6 .

\section{Model Description}

The GISS GCM $2^{\prime}$ is described by Rind and Lerner [1996] and by Rind et al. [1999]. Relative to the earlier
GISS GCM 2 [Hansen et al., 1983], the GCM 2 ' includes improved schemes for the boundary layer and land surface processes. It also uses the second-order moments scheme of Prather [1986] for heat and moisture advection, and a fourth-order scheme for advection of momentum. The convection scheme includes entrainment, detrainment, and downdrafts, and condensed water in clouds is traced through the hydrological cycle [ $\mathrm{Del}$ Genio et al., 1996]. The GCM $2^{\prime}$ version implemented here has a resolution of $4^{\circ}$ latitude and $5^{\circ}$ longitude, with nine vertical layers in a sigma coordinate system extending from the surface to $10 \mathrm{hPa}$ (seven layers up to $150 \mathrm{hPa}$ ). Tests of this version using the chemical tracers CFC-11, ${ }^{85} \mathrm{Kr}$, and ${ }^{222} \mathrm{Rn}$ indicate much improved (slower) rates of interhemispheric exchange and vertical transport compared to the GISS GCM 2 [Rind and Lerner, 1996].

Our chemical model largely follows previous off-line simulations of tropospheric ozonc- $\mathrm{NO}_{x}$-hydrocarbon chemistry using meteorological fields from the GISS GCM 2 [Wang et al., 1998b; Horowitz et al., 1998; Liang et al., 1998; Horowitz and Jacob, 1999]. We transport in the GCM $2^{\prime} 24$ chemical tracers, listed in Table 1. Two tracers, $\mathrm{NO}_{x}$ and $\mathrm{O}_{x}$, are chemical families. Tracer transport is calculated every 4 hours, using the same second-order moments scheme employed for heat and moisture advection. With a model top at $10 \mathrm{hPa}$ and coarse vertical resolution, the GCM $2^{\prime}$ cannot realistically simulate the residual circulation in the stratosphere nor the associated transport from the stratosphere into the troposphere [Rind et al., 1999]. Flux up-

Table 1. Chemical Tracers in the GCM

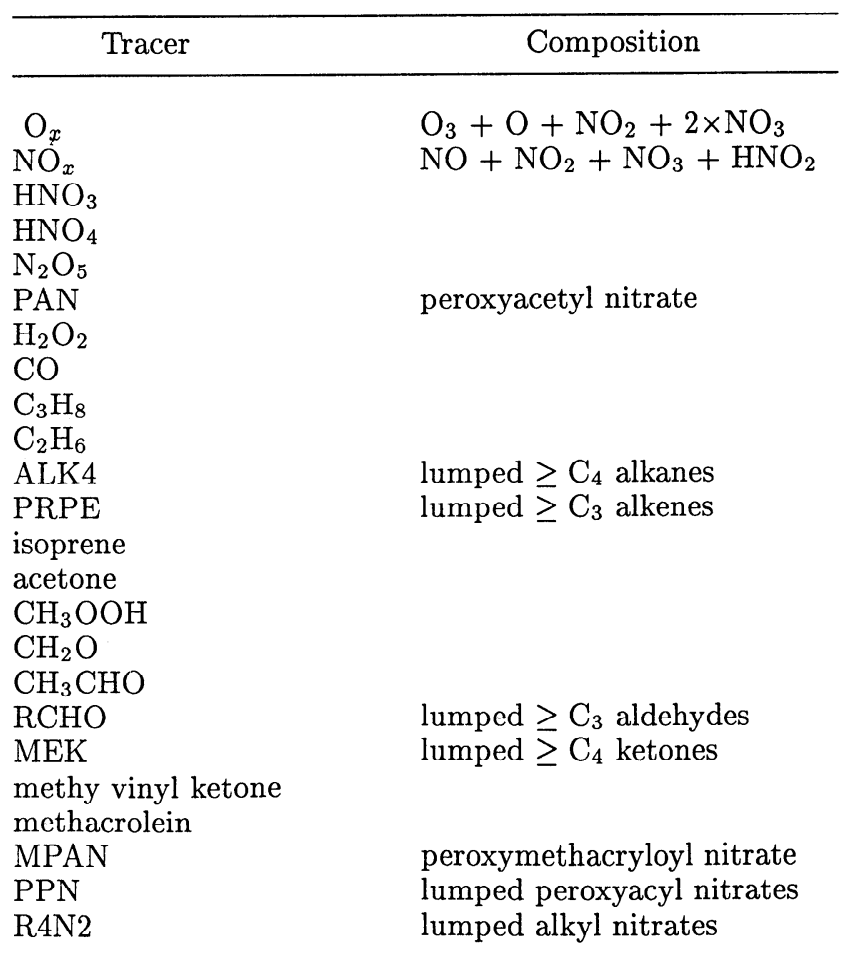


per boundary conditions are therefore applied between the seventh and eighth layers (about $150 \mathrm{hPa}$ ) to represent transport across the tropopause, as described by Wang et al. [1998b]. The flux upper boundary condition for ozone is based on the cross-tropopause air mass fluxes derived by Appenzeller et al. [1996] as a function of latitude and season, together with ozonesonde measurements at $100 \mathrm{hPa}$ at midlatitudes [Logan, 1999a]. Methane is not transported in the model but is specified instead at a uniform mixing ratio on the basis of observations (1.7 ppm for present-day, $0.7 \mathrm{ppm}$ for preindustrial).

The chemical mechanism in the model is described by Horowitz et al. [1998]. It includes 80 chemical species and over 400 chemical reactions. Complete decomposition pathways are included for five NMHCs: ethane, propane, a lumped $\mathrm{C}_{4-5}$ alkane, propene, and isoprene. Heterogeneous hydrolysis of $\mathrm{N}_{2} \mathrm{O}_{5}$ in sulfate aerosols is included with a reaction probability of 0.1 and using global sulfate fields from Chin et al. [1996]. The chemical mechanism is integrated over 4-hour time steps with a fast Gear solver [Jacobson and Turco, 1994]. Photolysis rates are calculated using a six-stream radiative transfer code for the Rayleigh scattering atmosphere with reflective clouds [Logan et al., 1981; Spivakovsky et al., 1990]. Dry deposition is calculated with a resistance-in-series scheme [Wang et al., 1998b]. Wet deposition of $\mathrm{HNO}_{3}$ and $\mathrm{H}_{2} \mathrm{O}_{2}$ follows the scheme developed by Koch et al. [1999] for scavenging of soluble gases in the GCM $2^{\prime}$. This scheme ensures consistency with the GCM air and condensed-water fluxes during wet convective events.

Emission schemes in the model are similar to those implemented by Wang et al. [1998b]. Anthropogenic emissions include fossil fuel combustion and industrial sources for $\mathrm{NO}_{x}, \mathrm{CO}$, and NMHCs; soil emissions of $\mathrm{NO}_{x}$ from fertilizer application; wood fuel emissions of $\mathrm{CO}$; and biomass burning emissions of $\mathrm{NO}_{x}, \mathrm{CO}$, and NMHCs. Table 2 lists the global annual emissions for all the emitted species in the model. Chemical rates, dry deposition fluxes, and natural emission fluxes vary locally as a function of the GCM environmental variables, as described by Wang et al. [1998b].

The preindustrial simulation uses the same GCM meteorological fields as the present-day simulation. We also chose to use the same cross-tropopause flux of ozone as in the present-day simulation, given that little is known about trends in this flux. All anthropogenic emissions are shut off except for biomass burning emissions, which are reduced to $10 \%$ of their present-day value.

The GCM employs the correlated $k$-distribution method to determine radiative absorption and emission in the longwave and shortwave spectral regions [Hansen et al., 1983]. Absorbers in the longwave include $\mathrm{H}_{2} \mathrm{O}$, $\mathrm{CO}_{2}, \mathrm{~N}_{2} \mathrm{O}, \mathrm{CH}_{4}$, and ozone; and in the shortwave $\mathrm{H}_{2} \mathrm{O}$, $\mathrm{CO}_{2}, \mathrm{NO}_{2}, \mathrm{O}_{2}$, and ozone. Important absorption features of tropospheric ozone include the 9.6 and $14 \mu \mathrm{m}$ bands in the infrared and the Huggins bands (310-
Table 2. Global Emission Inventories for the Present-Day Atmosphere

\begin{tabular}{lr}
\hline \multicolumn{1}{c}{ Species } & Value \\
\hline $\mathrm{NO}_{x}$ & \\
Fossil fuel combustion & 20 \\
Biomass burning & 11 \\
Soil (natural) & 3.9 \\
Soil (fertilizer) & 0.5 \\
Lightning & 3.5 \\
Aircraft & 0.5 \\
Stratosphere & 0.1 \\
Total & 40 \\
CO & \\
Fossil fuel combustion & 390 \\
Wood fuel combustion & 130 \\
Biomass burning & 510 \\
Total & 1030 \\
Isoprene & \\
Vegetation & 550 \\
Ethane & \\
Industrial & 6.2 \\
Biomass burning & 2.4 \\
Total & 8.6 \\
$\geq$ C & \\
Industrial & \\
$\geq$ C & \\
Industrial alkenes & 30 \\
Biogenic sources & \\
Biomass burning & 14 \\
Total & 16 \\
Acetone & \\
Biomass burning & 38 \\
Biogenic sources & \\
Total & \\
& \\
\hline & \\
\hline
\end{tabular}

Units are $\mathrm{Tg} \mathrm{N} \mathrm{yr}^{-1}$ for $\mathrm{NO}_{x}, \mathrm{Tg} \mathrm{CO}$ $\mathrm{yr}^{-1}$ for $\mathrm{CO}$, and $\mathrm{TgC} \mathrm{yr}^{-1}$ for the other molecules. Values are annual means.

$400 \mathrm{~nm})$ and Chappuis bands (400-800 nm) in the ultraviolet and visible. A prescribed climatological distribution for ozone is used in the radiative heating calculations that drive the GCM meteorology. We also apply the same radiative transfer code at each time step and grid square to calculate local radiative budgets on the basis of the ozone concentrations simulated with the online chemical model. The radiative forcing from ozone is then obtained by comparing our computed radiative fluxes at the tropopause in the present-day and preindustrial simulations. Our radiative calculation does not feed back into the GCM climate; the present-day and preindustrial simulations use exactly the same meteorological fields.

All forcings calculated in this manner are instantaneous forcings [Hansen et al., 1997]. Many previous studies [e.g., Roelofs et al., 1997; van Dorland et al., 1997; Berntsen et al., 1997; Haywood et al., 1998] have calculated the "adjusted" radiative forcing, in which the stratospheric temperatures are permitted to relax to equilibrium following the radiative perturbation. The 
difference between instantaneous and adjusted forcings may be 10-20\% [Berntsen et al., 1997; Haywood et al., 1998].

To initialize the model meteorology, the GCM $2^{\prime}$ was run without chemistry for 10 years. Two 18-month simulations were then performed with chemistry for preindustrial and present-day conditions. We analyze the results from the last 12 months of these simulations.

\section{Evalulation of the Present-Day Simulation}

The simulation for the present-day atmosphere needs to be compared with observations. Because the GCM generates a typical meteorological year, not a specific year, the best comparisons are with statistics of measurements taken over many years. Such observations are available only for ozone (from the ozonesonde network) and for surface CO [Oltmans and Levy, 1994; Novelli et al., 1998; Logan, 1999b]. The global mean $\mathrm{OH}$ concentration in the model can be evaluated with the methyl chloroform lifetime inferred from observations [Prinn et al., 1995]. For other species, we must rely on sparse data from aircraft campaigns (B. Bradshaw et al., Observed distributions of nitrogen oxides in the remote free troposphere from NASA Global Tropospheric Experiments, submitted to Reviews of Geophysics, 1999). For comparison to model results, we average the aircraft data regionally.
A detailed evaluation of model results for an earlier simulation using GISS GCM 2 meteorological fields was presented by Wang et al. [1998c] (W98c). Our simulation differs mostly in its use of GCM $2^{\prime}$ meteorological fields and also in its improved chemical mechanism. We have conducted the full range of model evaluations presented in W98c and show here a small selection of results particularly relevant to the ozone simulation. Comparisons to the model results of W98c are also discussed.

\subsection{Carbon Monoxide}

Figure 1 compares model $\mathrm{CO}$ to observations at four surface sites. The model captures the seasonal variation of $\mathrm{CO}$, which peaks in late winter-early spring when $\mathrm{OH}$ abundances are lowest and, in the Southern Hemisphere, when biomass burning is most intense. The model overestimates $\mathrm{CO}$ at Cape Meares, on the coast of Oregon, because of averaging of emissions over the $4^{\circ}$ by $5^{\circ}$ grid scale. We also show in Figure 1 model results for the adjacent grid box west of Cape Meares. The agreement with observations is much improved. The model underestimates CO at Samoa, a discrepancy which we diagnose is due to insufficient cross-equatorial transport over the western Pacific in the GISS GCM $2^{\prime}$. Compared to W98c, the model has higher concentrations in the boundary layer and mid-troposphere over source regions (industrial continents at northern midlat-
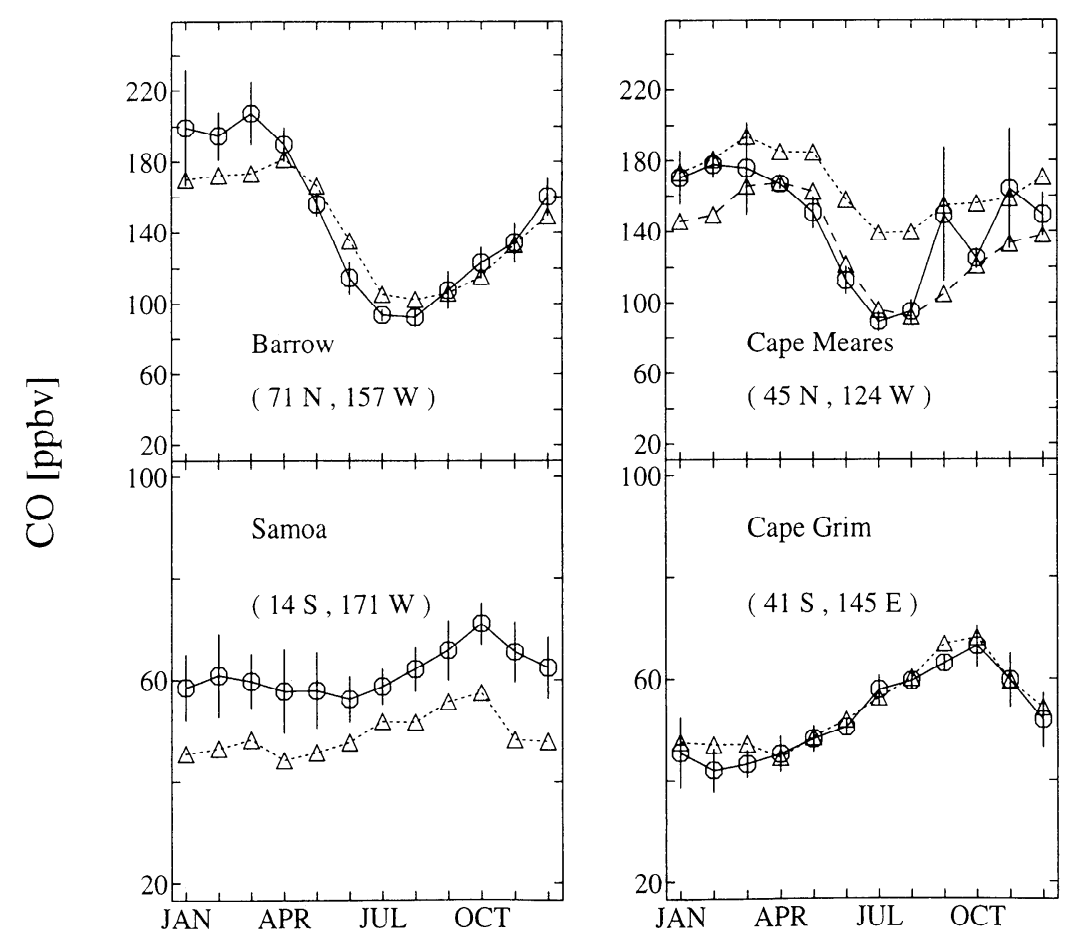

Figure 1. Comparison of observed with simulated monthly mean $\mathrm{CO}$ concentrations near the surface. Data are from Novelli et al. [1998]. Solid lines and open circles represent observations; dashed lines and triangles are model simulations. 
itudes and biomass burning areas in the tropics), which we attribute to improvement in the GCM convection scheme.

\subsection{Nitrogen Oxides}

Figure 2 (first column) compares model results for NO to aircraft observations. The figure also shows the standard deviation of the calculated mean $\mathrm{NO}$ value for the grid boxes in each region. The agreement is generally close, although the standard deviations are large in source regions.

Figure 2 also compares calculated profiles of $\mathrm{HNO}_{3}$ with aircraft measurements (second column). As in W98c and other global three-dimensional models [e.g., Lawrence and Crutzen, 1998; Hauglustaine et al., 1998], the model overestimates $\mathrm{HNO}_{3}$ in the remote tropo- sphere. Lawrence and Crutzen [1998] have recently proposed that gravitational settling of cirrus ice crystals, a process not included in the GISS GCM 2', may significantly reduce $\mathrm{HNO}_{3}$ abundances in the upper troposphere. New kinetic data for the reactions $\mathrm{NO}_{2}+\mathrm{OH}+\mathrm{M}$ and $\mathrm{HNO}_{3}+\mathrm{OH}$ [Brown et al., 1999], not included in our model, would also reduce $\mathrm{HNO}_{3}$ abundances in the free troposphere [Schultz et al., 1999]. Suppression of heterogeneous hydrolysis of $\mathrm{N}_{2} \mathrm{O}_{5}$ when the aerosol is dry would further reducc $\mathrm{HNO}_{3}[$ McKeen et al., 1997; Schultz et al., 1999].

The third column of Figure 2 compares simulated profiles of PAN to observations. Agreement is in general fairly good, to within a factor of 2 . The model appears to underestimate PAN in regions affected by biomass burning. Interpretation of this discrepancy is

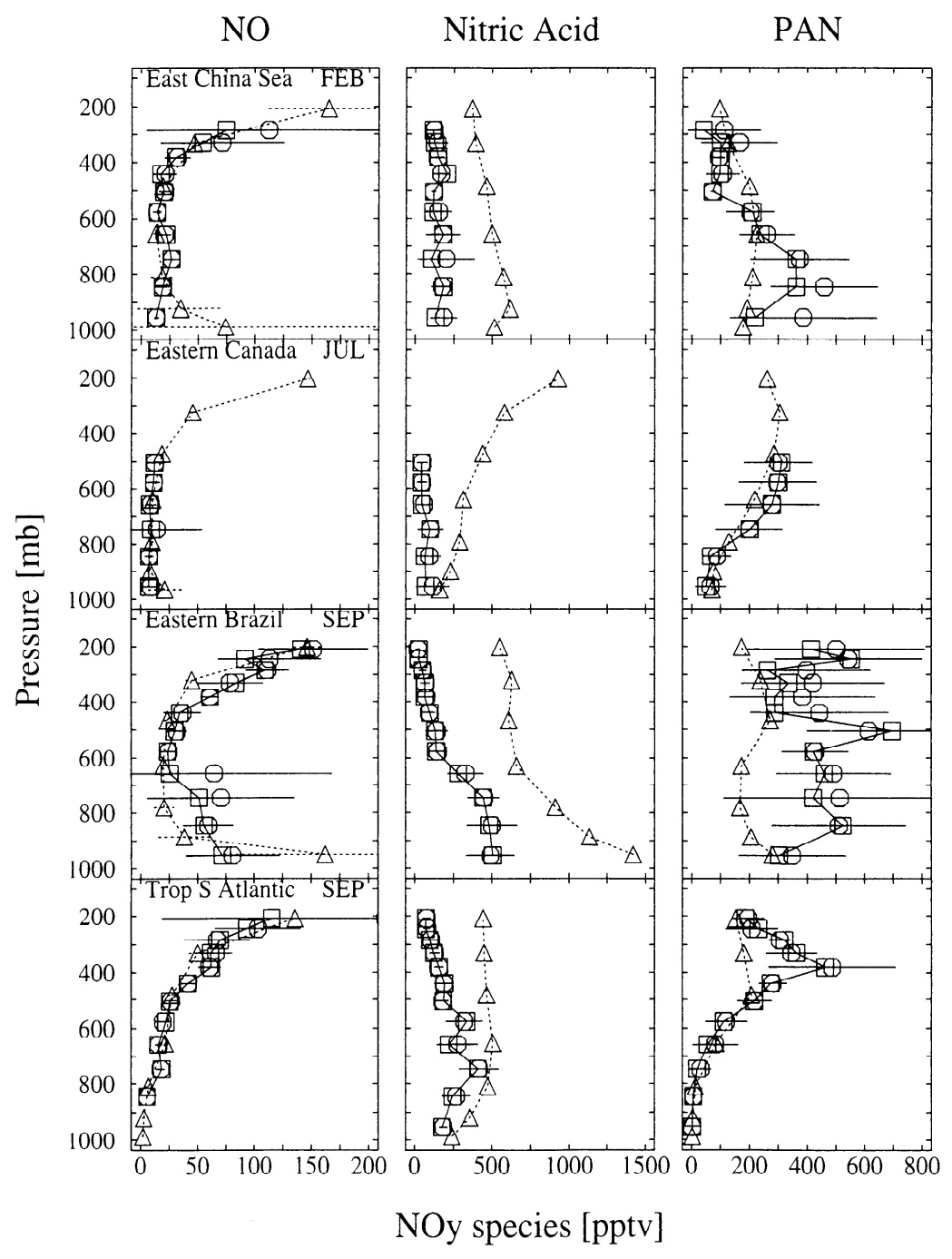

Figure 2. Comparison of observed with simulated vertical profiles of $\mathrm{NO}$ (first column), $\mathrm{HNO}_{3}$ (second column), and PAN (third column). The region for each row of panels is named in the NO panel. (See W98c for definition of the regions.) Open squares and solid lines are median obscrvations, with standard deviations represented by solid horizontal bars. Open triangles and dashed lines are monthly mean model concentrations averaged over the grid boxes composing each region. Dashed horizontal bars in the NO panels are the standard deviations for the model. 

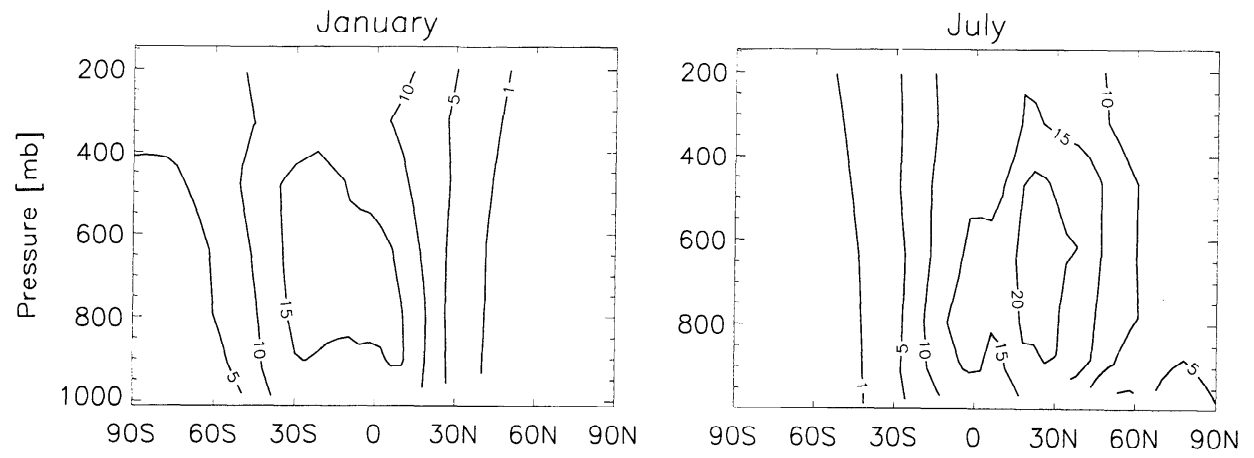

Figure 3. Calculated zonal mean $\mathrm{OH}$ concentrations $\left(10^{5}\right.$ molecules $\left.\mathrm{cm}^{-3}\right)$ in January and July.

difficult because biomass burning emissions may vary significantly from year to year and because the aircraft preferentially sampled biomass burning plumes.

\section{3. $\mathrm{OH}$ and $\mathrm{H}_{2} \mathrm{O}_{2}$}

Figure 3 shows the 24-hour averaged, zonal mean $\mathrm{OH}$ concentration fields calculated for January and July. Maximum $\mathrm{OH}$ concentrations are found in the midtroposphere over the tropics, reflecting the abundances of ultraviolet radiation and water vapor. Our $\mathrm{OH}$ concentration fields agree closely with the MOZART global model simulation of Hauglustaine et al. [1998], but are about $25 \%$ lower at the maximum than those reported by W98c and by C. M. Spivakovsky et al. (Three-dimensional climatological distribution of tro- pospheric OH, submitted to Journal of Geophysical Research, 1999; hereinafter referred to as submitted paper.) A key reason for the discrepancy with W98c is that we calculate higher concentrations of $\mathrm{CO}$, a sink of $\mathrm{OH}$, in the midtroposphere over the tropics. Analysis of the discrepancy with C. M. Spivakovsky et al. (submitted paper, 1999), on the other hand, shows that we calculate about $25 \%$ lower ozone concentrations in the mid-troposphere over the tropics, leading to lower $\mathrm{OH}$ abundances in that region. We calculate the globally averaged lifetime of methyl chloroform against oxidation by $\mathrm{OH}$ below $150 \mathrm{hPa}$ to be 6.2 years, significantly longer than the value of $4.8 \pm 0.3$ years estimated by Prinn et al. [1995] from observed methyl chloroform concentrations and global inventories.

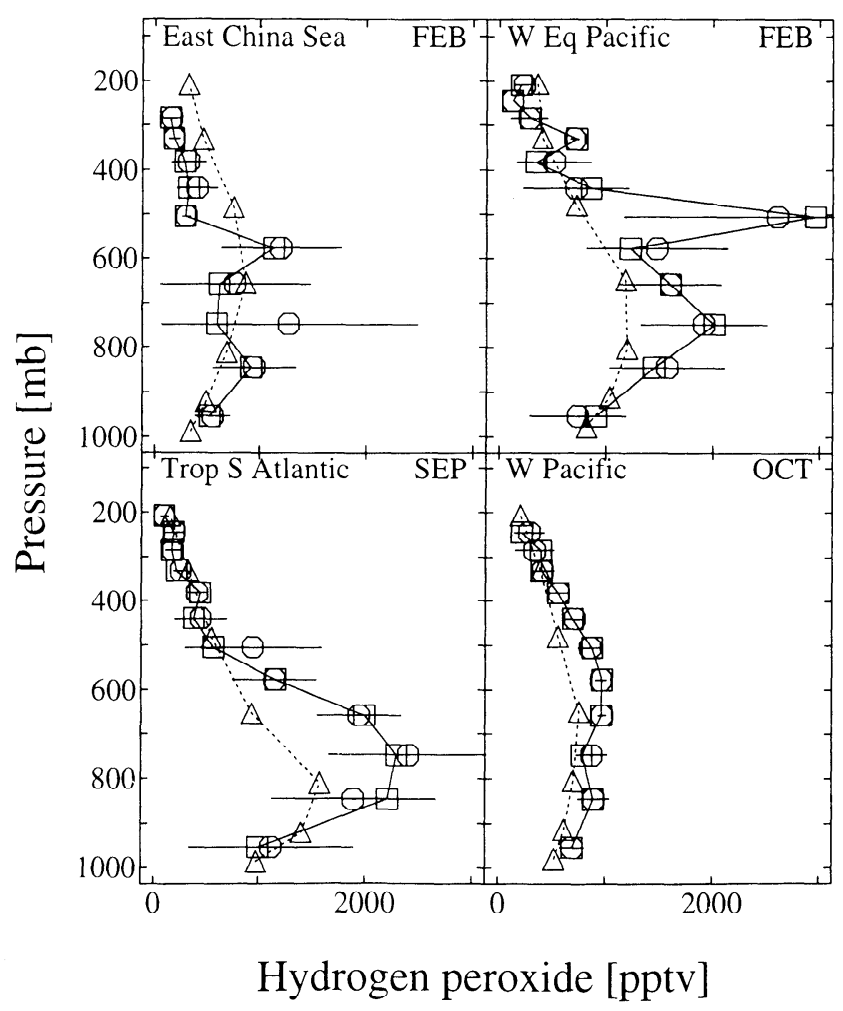

Figure 4. Same as Figure 2 but for $\mathrm{H}_{2} \mathrm{O}_{2}$. 
Comparison of our model results with aircraft observations for $\mathrm{H}_{2} \mathrm{O}_{2}$, the major sink of odd hydrogen and a sensitive indicator of $\mathrm{HO}_{2}$ concentrations, is presented in Figure 4. The figure shows fair agreement except in biomass burning regions where again the model is too low.

\subsection{Ozone}

Simlulated ozone concentrations near the surface and at $500 \mathrm{hPa}$ for January and July are shown in Figure 5 . Ozone concentrations are high over industrial regions in the Northern Hemisphere in summer and over biomass burning regions in the tropics. Figures 6 and 7 compare the observed and simulated seasonal variations at 800 and $500 \mathrm{hPa}$, respectively, and Figure 8 compares vertical profiles. The observations are multiyear averages taken from ozonesonde measurements [Logan, 1999b]. At most sites the model capturcs the monthly mean of ozone to within about $10 \mathrm{ppb}$. There are some important discrepancics, such as underestimates in biomass burning regions or over Wallops Island at $800 \mathrm{hPa}$ during summer. These discrepancies are comparable to those in W98c. The model reproduces the observed vertical gradient of ozone much better than W98c, in which the gradient was too weak, particularly in the tropics. This improvement can be attributed to the better convection in the GCM $2^{\prime}$.

A global budget of odd oxygen $\left(\mathrm{O}_{x}\right)$ in the presentday scenario is presented in Table 3 . For the purpose of this budget, $\mathrm{O}_{x}$ is defined as the sum of ozone, $\mathrm{O}, \mathrm{NO}_{2}$, $2 \times \mathrm{NO}_{3}, \mathrm{HNO}_{4}, 3 \times \mathrm{N}_{2} \mathrm{O}_{5}$, and the peroxyacylnitrates; ozone makes up over $99 \%$ of $\mathrm{O}_{x}$ globally. Calculated $\mathrm{O}_{x}$ production and loss rates $-4300 \mathrm{Tg} \mathrm{\textrm {yr } ^ { - 1 }}$ and 3960 $\mathrm{Tg} \mathrm{yr}^{-1}$, respectively - are on the high side but within the range of those calculated by other models (3018$4500 \mathrm{Tg} \mathrm{yr}^{-1}$ for production rates and $2511-4000 \mathrm{Tg}$ $\mathrm{yr}^{-1}$ for loss rates [Hauglustaine et al., 1998]). Ozone loss by dry deposition in our model, $760 \mathrm{Tg} \mathrm{yr}^{-1}$, is again within the range of values reported in other threedimensional model studies (534-1100 $\mathrm{Tg} \mathrm{yr}^{-1}$ ). For the transport of ozone from the stratosphere, our model calculates $390 \mathrm{Tg} \mathrm{yr}^{-1}$, a rate nearly identical to that estimated by MOZART but at the low end in the range of rates calculated by other models (391-846 ${\left.\mathrm{Tg} \mathrm{.} \mathrm{yr}^{-1}\right)}^{-1}$ [Hauglustaine et al., 1998].

\section{Preindustrial Simulation}

In Figure 9, we show simulated ozone near the surface in January and July for the preindustrial atmo-
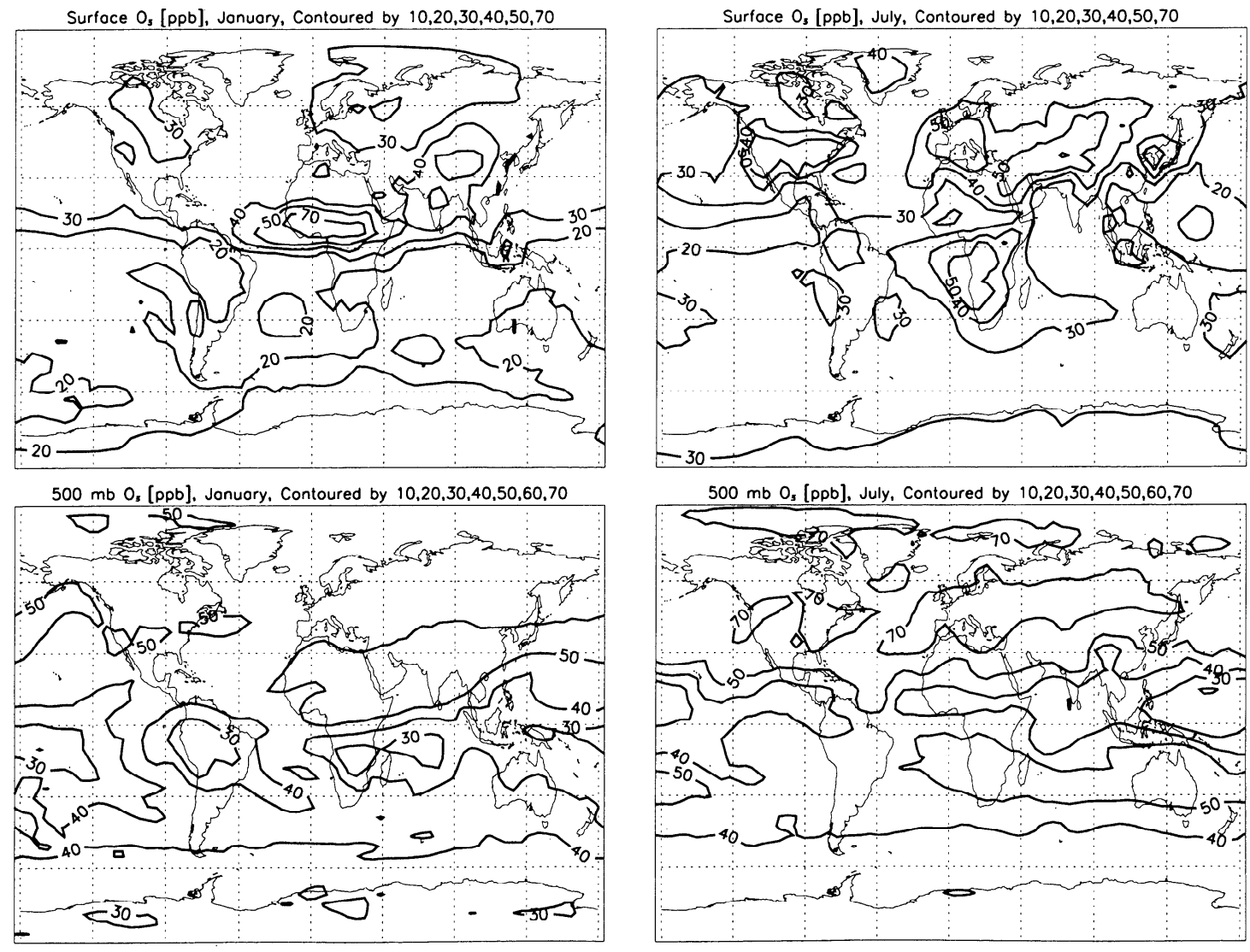

Figure 5. Simulated monthly mean ozone concentrations (in ppb) near the surface and at 500 $\mathrm{hPa}$ in January and July. 


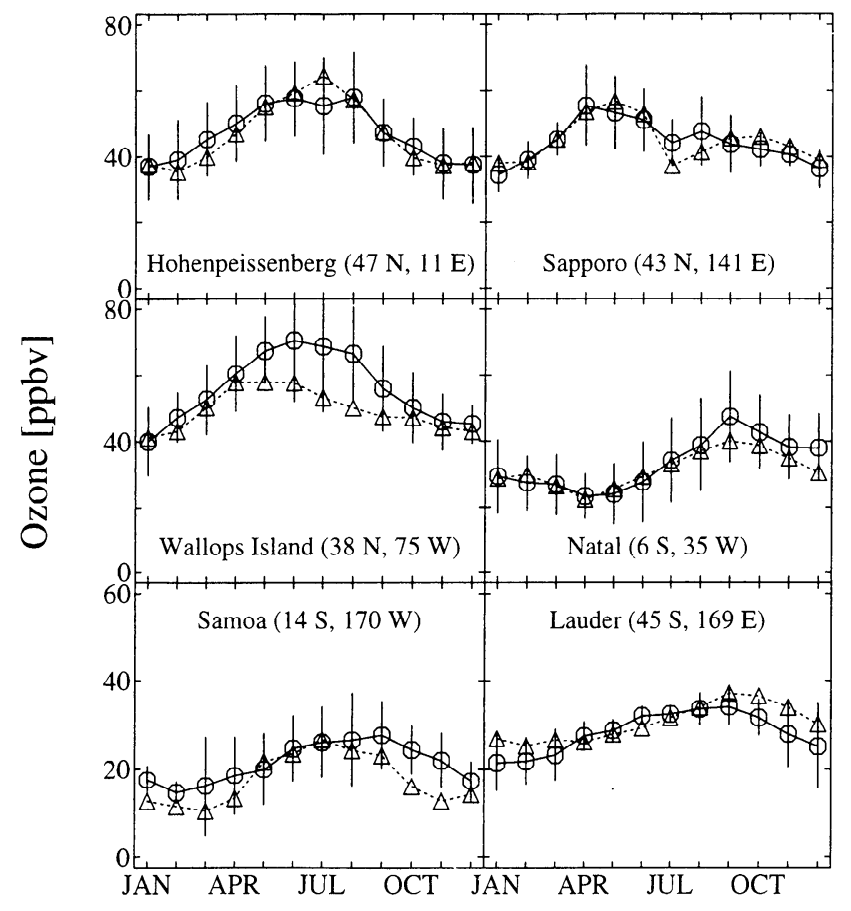

Figure 6. Comparison of observed with simulated monthly mean ozone concentrations at $800 \mathrm{hPa}$. Ozonesonde data are from Logan [1999b]. Solid lines and open circles are observations; the vertical bars are standard deviations. Dashed lines and open triangles are model simulations.

sphere. Our results are similar to those obtained by Wang and Jacob [1998] (WJ98) with the GISS GCM 2 model. Ozone mixing ratios are in the $10-20 \mathrm{ppb}$ range, with higher values in winter, when ozone transport from the stratosphere is greater and photochemical loss is less. As discussed by WJ98, preindustrial simulations in global three-dimensional models yield surface ozone concentrations 5-10 ppb larger than reconstructed 19th century observations for sites in Europe and South America [Marenco et al., 1994]. Reasons for this discrepancy are not clear.

Annually and zonally averaged relative changes in the concentrations of ozone, $\mathrm{OH}, \mathrm{NO}_{x}$, and $\mathrm{CO}$ from the preindustrial to the present-day scenario are shown in Figure 10. As in WJ98, we find that ozone has doubled in the middle and lower troposphere of the Northern Hemisphere since preindustrial times and has increased by $20-100 \%$ elsewhere in the troposphere. The global burden of tropospheric ozone has increased about $56 \%$ since preindustrial times, from $230 \mathrm{Tg}$ to $360 \mathrm{Tg}$ (Table 3 ), in close agreement with WJ98.

Changes in $\mathrm{OH}$ since preindustrial times reflect competing influences from increases in ozone and $\mathrm{NO}_{x}$, which tend to boost $\mathrm{OH}$, and increases in $\mathrm{CO}$ and hydrocarbons, which tend to depress $\mathrm{OH}$ [Thompson, 1992]. We find that $\mathrm{OH}$ abundances have increased by as much as $50 \%$ over the polluted regions in the Northern Hemisphere, due to large increases in $\mathrm{NO}_{x}$ and ozone, and have declined by $10-20 \%$ over the remote atmosphere, where the effect of increasing $\mathrm{CO}$ and $\mathrm{CH}_{4}$ dominates. We calculate that the mass-weighted global mean $\mathrm{OH}$ concentration has decreased by $16 \%$ since preindustrial times, from $1.1 \times 10^{6}$ molecules $\mathrm{cm}^{-3}$ to $9.2 \times 10^{5}$ molecules $\mathrm{cm}^{-3}$. WJ98 calculated a percent change of only $9 \%$. One reason for this difference is that we calculate increases in CO of up to $600 \%$ over the northern midlatitudes, where WJ98 reported increases in CO of only $400 \%$. Most other model studies concur that global $\mathrm{OH}$ abundances have declined since preindustrial times [Thompson, 1992], though Berntsen et al. [1997] calculate a $6 \%$ increase in $\mathrm{OH}$.

In Figure 11, we present by season the difference in tropospheric ozone column between the preindustrial and present-day simulations, in Dobson units (DU), where $1 \mathrm{DU}=2.7 \times 10^{16}$ molecules $\mathrm{O}_{3} \mathrm{~cm}^{-2}$. The differences range from less than $5 \mathrm{DU}$ over remote regions to as much as 20-25 DU over polluted areas in Northern Hemisphere summer. Observed present-day tropospheric ozone columns range from less than $20 \mathrm{DU}$ over the remote Pacific to more than $60 \mathrm{DU}$ over polluted areas [Fishman et al., 1990].

\section{Radiative Forcing}

Plate 1 (top panels) shows the seasonally averaged longwave radiative forcing by anthropogenic ozone computed in the model for December-January-February (DJF) and June-July-August (JJA). Figure 12 shows these longwave forcings zonally averaged. The forcing correlates with the change in ozone. In DJF, the

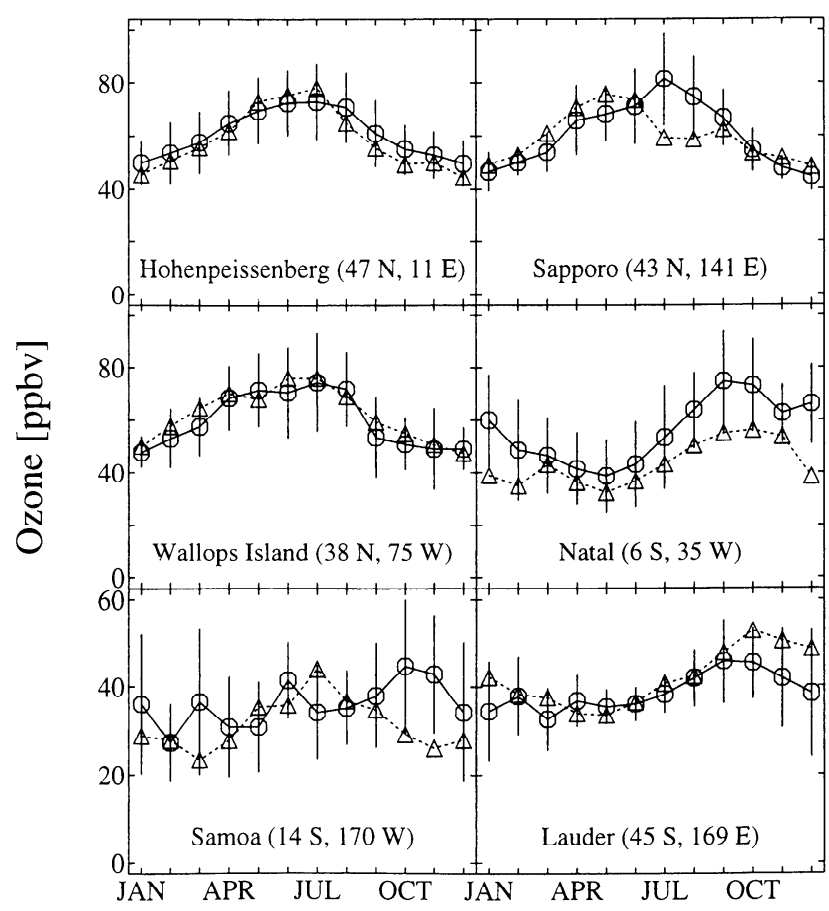

Figure 7. Same as for Figure 6, but for $500 \mathrm{hPa}$. 


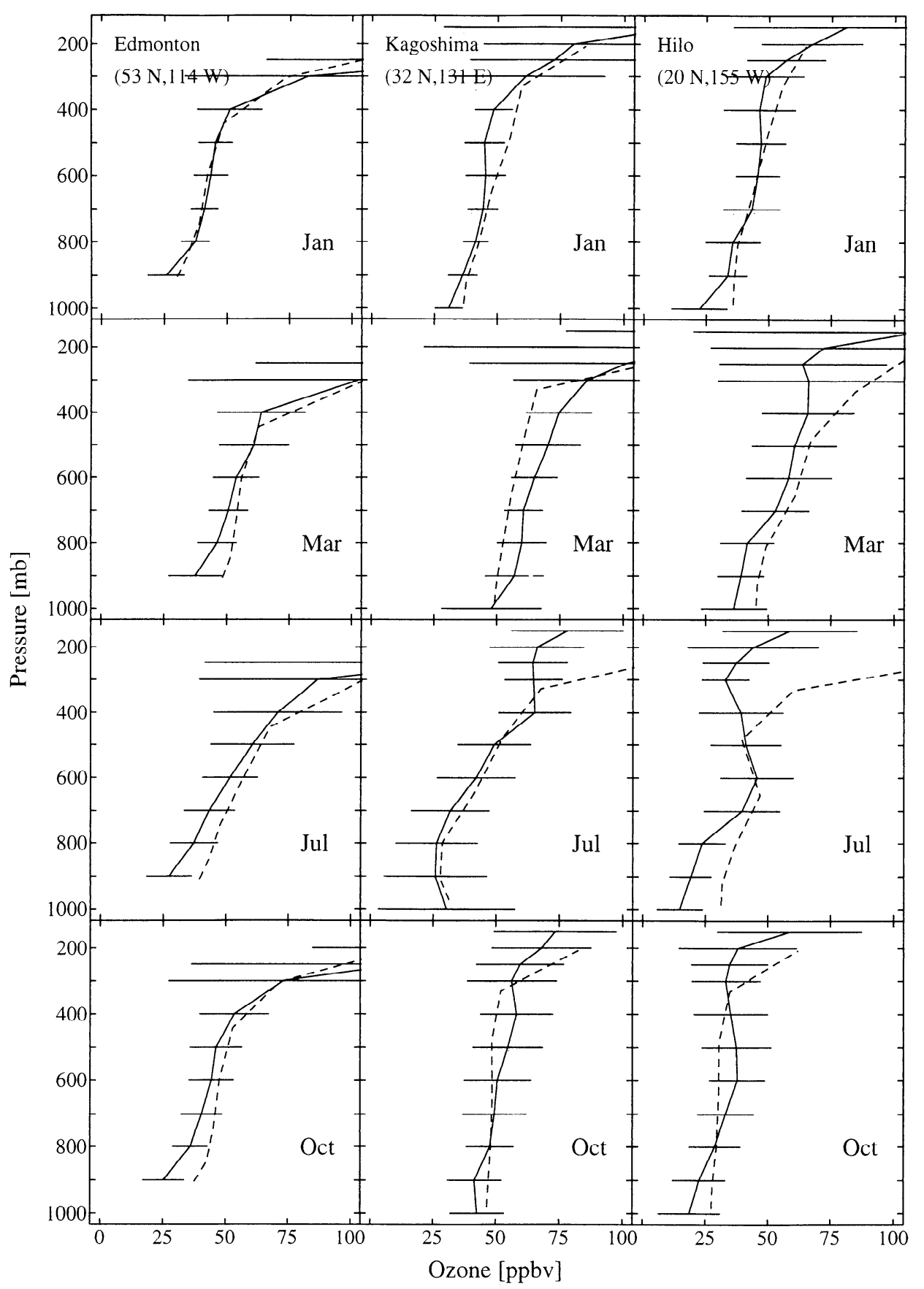

Figure 8. Comparison of observed with simulated monthly averaged ozone profiles. Ozonesonde data are from Logan [1999b]. Line symbols are as in Figure 6. Horizontal bars are standard deviations in the measurements.

radiative forcing reaches a maximum of $0.8 \mathrm{~W} \mathrm{~m}^{-2}$ over sub-Saharan Africa due to biomass burning pollution. In March-April-May (not shown), increasing solar insolation in the Northern Hemisphere causes ozone abundances to increase together with the longwave radiative forcing; maximum forcings $\left(0.8-1.2 \mathrm{~W} \mathrm{~m}^{-2}\right)$ are over the Sahara and India. In JJA the forcing is highest at northern midlatitudes $\left(0.8-1.1 \mathrm{~W} \mathrm{~m}^{-2}\right)$ and much weaker over India because of the monsoon. Finally, in September-October-November (not shown), longwave forcings decrease over the Northern Hemisphere but increase in the Southern Hemisphere due to biomass burning pollution from South America and southern Africa. The longwave forcings generated over sub-Saharan Africa due to biomass burning in boreal winter are greater than those generated by biomass burning during austral spring over South America. The reason for this difference, discussed in further detail below, involves the difference in cloudiness between the two regions. 


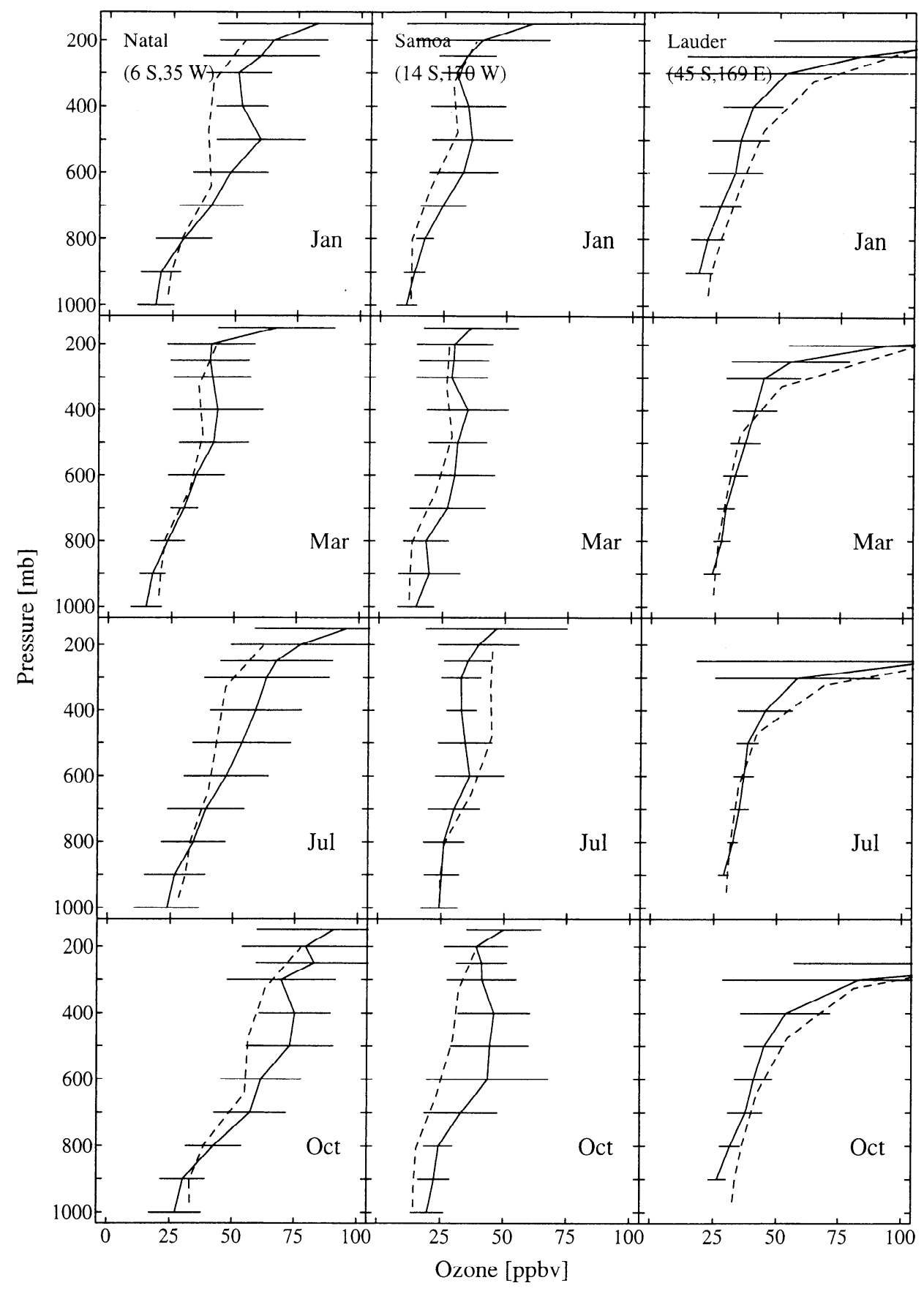

Figure 8. (continued)

The maximum longwave forcings are at subtropical latitudes (Figure 12), except during boreal summer, when the maximum forcings are at about $50^{\circ} \mathrm{N}$. The forcing is relatively weak at equatorial latitudes $\left(10^{\circ} \mathrm{S}-\right.$ $\left.10^{\circ} \mathrm{S}\right)$. As we shall see below, the subtropical maxima reflect the large temperature differences between Earth's surface and the tropopause in these regions, and the equatorial dips are due in part to the influence of clouds.

Plate 1 and Figure 12 also show the shortwave radiative forcing from anthropogenic ozone. The forcings are greatest, as much as $0.7 \mathrm{~W} \mathrm{~m}^{-2}$, over the Arctic and Greenland in Northern Hemisphere summer. The high albedo of the Arctic region and Greenland means that more sunlight is reflected and can then be intercepted by the added ozone. In Northern Hemisphere winter there is little or no sunlight reaching the high latitudes, and the shortwave forcing drops to zero. Forcings are less in the Southern than in the Northern Hemisphere summer, simply because less anthropogenic ozone is generated in the former. 
Table 3. Global Budgets for Tropospheric Ozone in the Present-Day and Preindustrial Simulations

\begin{tabular}{lrr}
\hline & $\begin{array}{c}\text { Present-Day } \\
\text { Atmosphere }\end{array}$ & $\begin{array}{c}\text { Preindustrial } \\
\text { Atmosphere }\end{array}$ \\
\hline Sources & & \\
$\quad$ In situ chemical production & 4330 & 1620 \\
$\quad$ Transport from stratosphere & 390 & 390 \\
$\quad$ Total sources & 4720 & 2010 \\
Sinks & & \\
$\quad$ In situ chemical loss & 3960 & 1650 \\
Dry deposition & 760 & 360 \\
Total sinks & 4720 & 2010 \\
$\quad$ & & \\
Burden (Tg O & & \\
Residence time (days) & 360 & 42 \\
& 28 &
\end{tabular}

Units are $\mathrm{Tg} \mathrm{O}_{3} \mathrm{yr}^{-1}$. Budgets are for the odd oxygen family defined as the sum of ozone, $\mathrm{O}, \mathrm{NO}_{2}, 2 \times \mathrm{NO}_{3}, \mathrm{HNO}_{4}, 3 \times \mathrm{N}_{2} \mathrm{O}_{5}$, and the peroxyacylnitrates.

In Plate 2, we add the longwave and shortwave forcings to obtain the total radiative forcing due to anthropogenic ozone for the four seasons. In JJA the combined forcings are more than $1.0 \mathrm{~W} \mathrm{~m}^{-2}$ in some regions over Europe, southeastern and central Asia, the western United States, and the Arctic. These local forcings are nearly comparable to the globally averaged forcing since preindustrial times from anthropogenic $\mathrm{CO}_{2}, 1.6$ $\mathrm{W} \mathrm{m} \mathrm{m}^{-2}$ [Houghton et al., 1995]. As seen in Plate 1, the shortwave forcing is an important contributor to the total forcing at high latitudes.

The average total (shortwave+longwave) forcing for the year in the Northern Hemisphere is $0.53 \mathrm{~W} \mathrm{~m}^{-2}$; for the Southern Hemisphere it is $0.34 \mathrm{~W} \mathrm{~m}^{-2}$. The global average total forcing for the year is $0.44 \mathrm{~W} \mathrm{~m}^{-2}$ (0.35 longwave +0.09 shortwave). This value is higher than the average instantaneous radiative forcing obtained by other three-dimensional model studies, about $0.35 \pm 0.03$ $\mathrm{W} \mathrm{m}^{-2}$ [Chalita et al., 1996; Berntsen et al., 1997; Brasseur et al., 1998; Haywood et al., 1998; Kiehl et al., 1999]. (The average adjusted radiative forcing reported in other studies is, as expected, less than the average instantaneous forcing, about $0.33 \pm 0.06 \mathrm{~W} \mathrm{~m}^{-2}$ [van Dorland et al., 1997; Berntsen et al., 1997; Roelofs et al., 1997; Haywood et al., 1998; Stevenson et al., 1998].) One possible reason for our higher value is that we compute a higher change for the tropospheric ozone burden than at least some of the other authors. (Not all authors report this change.) We calculate a change of $130 \mathrm{Tg}$ ozone; the average change of three other models is $98 \mathrm{Tg}$ ozone [Roelofs et al., 1997; Berntsen et al., 1997; Haywood et al., 1998]. Our value for the global mean, instantaneous radiative forcing per DU of ozone, $0.034 \mathrm{~W} \mathrm{~m}^{-2} \mathrm{DU}^{-1}$, is comparable to that
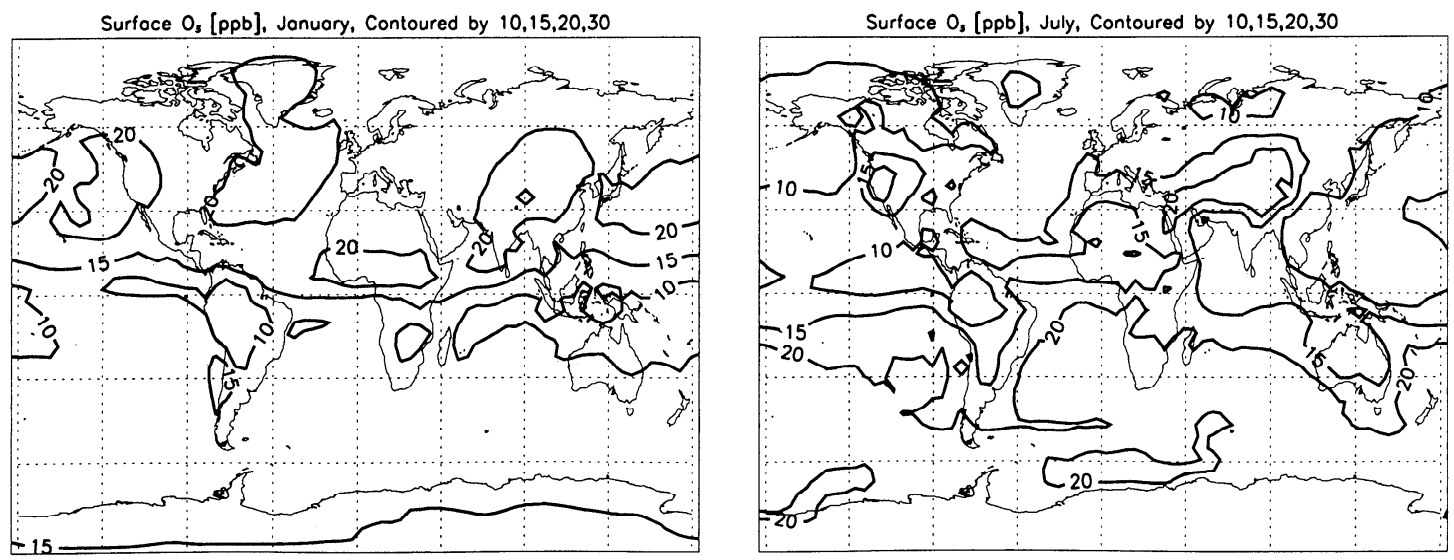

Figure 9. Simulated ozone concentrations (in $\mathrm{ppb}$ ) near the surface for the preindustrial atmosphere in January and July. 

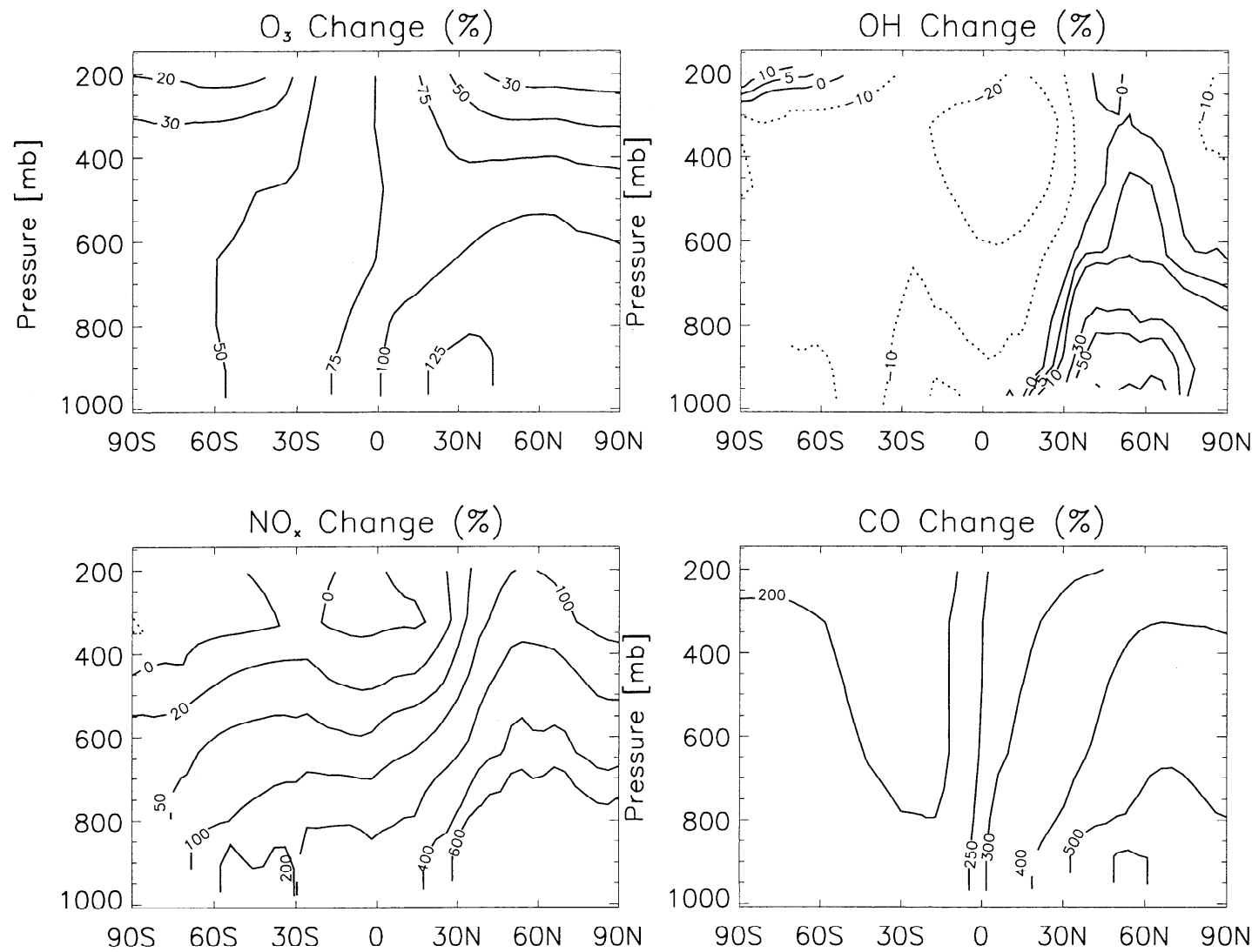

Figure 10. Percentage change of zonally averaged annual mean ozone, $\mathrm{OH}, \mathrm{NO}_{x}$, and $\mathrm{CO}$ concentrations from the preindustrial to the present-day simulation.

obtained from other models, $0.036-0.039 \mathrm{~W} \mathrm{~m}^{-2} \mathrm{DU}^{-1}$ [Berntsen et al., 1997; Haywood et al., 1998].

Four studies present plots of the annual mean total radiative forcings [Berntsen et al., 1997; Haywood et al., 1998; Stevenson et al., 1998; Kiehl et al., 1999]. In general, the distribution of our annual mean forcings (not shown) compares well with the distributions of these four studies, except our maximum forcings tend to be higher, $1.0 \mathrm{~W} \mathrm{~m}^{-2}$ versus $0.7-0.9 \mathrm{~W} \mathrm{~m}^{-2}$ in the other studies. Compared to Kiehl et al. [1999], we calculate lower annual mean forcings over the South Atlantic (0.6 $\mathrm{W} \mathrm{m} \mathrm{m}^{-2}$ versus $0.8 \mathrm{~W} \mathrm{~m}^{-2}$ ), but higher values over the Sahara $\left(0.8 \mathrm{~W} \mathrm{~m}^{-2}\right.$ versus $\left.0.5 \mathrm{~W} \mathrm{~m}^{-2}\right)$. Roelofs et al. [1997] present seasonal mean plots for DJF and JJA; Chalita et al. [1996] and van Dorland et al. [1997] give monthly mean plots for selected months. Compared to these three studies, we calculate higher forcings over the Arctic during boreal summer-more than $1.0 \mathrm{~W} \mathrm{~m}^{-2}$ versus $0.4-0.6 \mathrm{~W} \mathrm{~m}^{-2}$. Our seasonal mean distributions compare well with Roelofs et al. [1997], but our monthly mean distributions show higher maxima compared to Chalita et al. [1996] and van Dorland et al. [1997]. For example, we calculate as much as 1.1 $\mathrm{W} \mathrm{m} \mathrm{m}^{-2}$ for July over parts of Europe, Asia, and North America (not shown), while the other studies obtained maxima of only $0.8-1.0 \mathrm{~W} \mathrm{~m}^{-2}$.

Finally, our annual mean shortwave radiative forcings (not shown) have a steeper meridional gradient than forcings calculated by Berntsen et al. [1997] or by Haywood et al. [1998]. Though our global mean shortwave forcing of $0.09 \mathrm{~W} \mathrm{~m}^{-2}$ is only slightly higher than the forcings obtained by Berntsen et al. [1997] (0.07-0.08 $\left.\mathrm{W} \mathrm{m}^{-2}\right)$, we calculate more than twice the shortwave forcing over the Arctic on an annual average $\left(0.30 \mathrm{~W} \mathrm{~m}^{-2}\right.$ versus $\left.0.12-0.15 \mathrm{~W} \mathrm{~m}^{-2}\right)$.

To determine under what conditions an addition of ozone has the greatest radiative forcing impact, we have normalized the radiative forcings in the model to the change in ozone in DU for that column. Figure 13 shows the zonally averaged, normalized forcings for the months of January and September. We chose these months to show the differences between solsticc and equinox conditions and to highlight the effect of biomass burning in the Southern Hemisphere in September. Normalization removes much of the variability in the calculated radiative forcings (compare Figure 12 to Figure 13). The normalized longwave forcings peak in the subtropics and decrease markedly toward the poles, while the shortwave forcings peak over the sunlit polar latitudes. Compensation between longwave and shortwave forcings results in little latitudinal gradient for the total forcing, except near the dark and cold poles.

What accounts for the variance of the normalized longwave forcing with latitude? We examined two factors: (1) the temperature difference between Earth's 

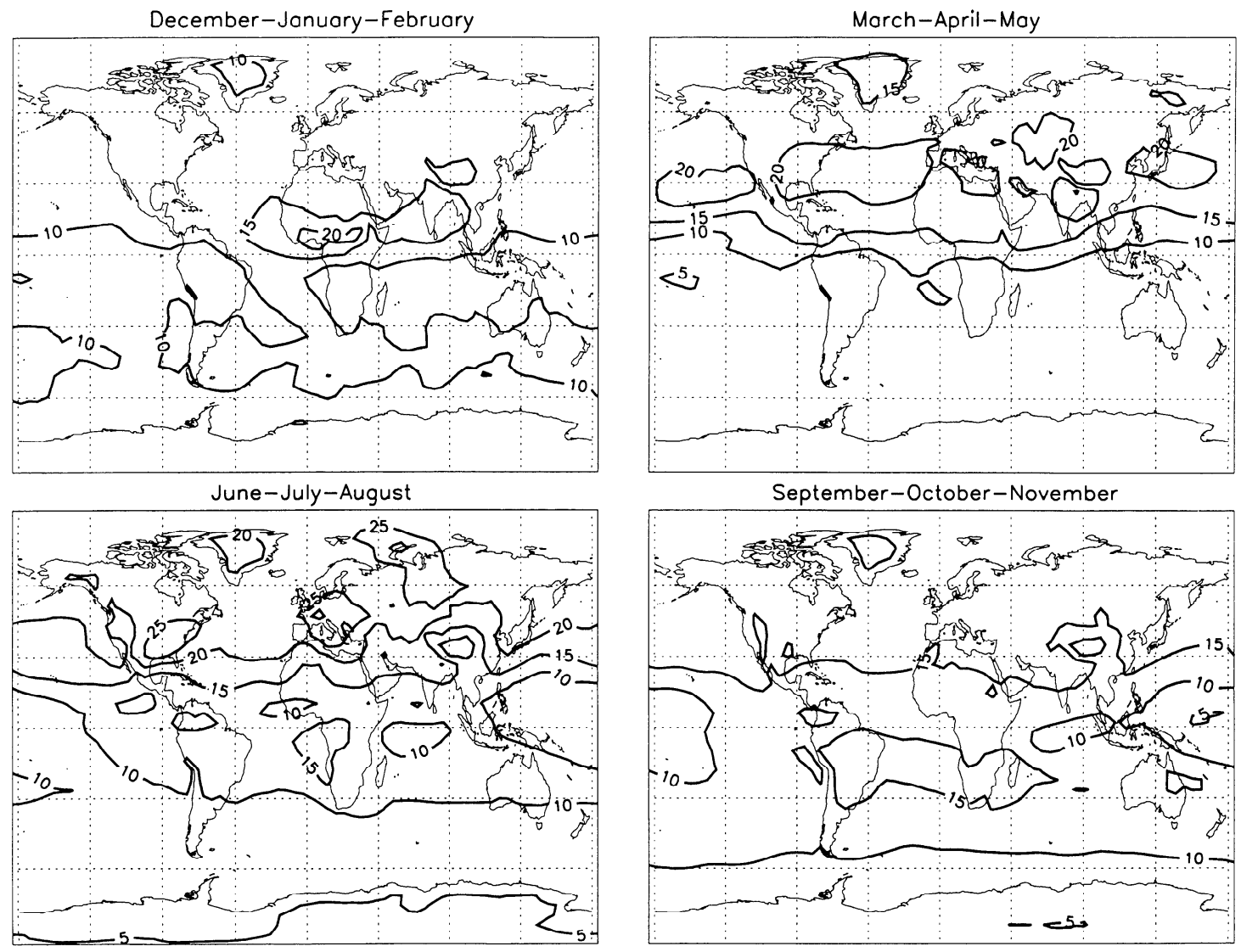

Figure 11. Seasonally averaged ozone column changes computed by the model from preindustrial times to the present, in Dobson units. $\left(1 \mathrm{DU}=2.7 \times 10^{16}\right.$ molecules $\mathrm{O}_{3} \mathrm{~cm}^{-2}$.) Contour intervals are at $5,10,15,20$, and $25 \mathrm{DU}$.

surface and the tropopause and (2) the cloud optical depth. In Figure 14, we plot the normalized longwave forcing as a function of the temperature difference between the surface and the tropopause in the corresponding grid square. The temperature difference between Earth's surface and the tropopause is a rough measure of how much energy can be trapped by the added ozone. Indeed, the plots show a strong positive correlation between normalized longwave forcing and temperature difference at latitudes poleward of about $20^{\circ}$. Over Antarctica (small temperature difference), the normalized forcing can actually be negative due to a temperature inversion, with an extremely cold surfacc. At latitudes equatorward of $20^{\circ}$ (large temperature differcnce), the correlation between longwave forcing and temperature difference breaks down.

A second factor contributing to variation of the normalized longwave forcing is cloud optical depth. Clouds absorb outgoing longwave radiation in the $9.6 \mu \mathrm{m}$ ozone band and thus limit the radiative forcing effect of added ozone. Figure 15 shows the normalized longwave radiative forcing versus monthly mean cloud optical depth in the mid- and upper troposphere $(740-150 \mathrm{hPa})$ for 0-20 latitude in September. The negative correlation is apparent. The cloud effect explains the lower nor- malized forcing at equatorial compared to subtropical latitudes (Figure 15).

An important question to ask is whether calculating radiative forcings with on-line chemistry, as we have done here, leads to results significantly different from those obtained with monthly or seasonally averaged ozone distributions as in most previous studies. To answer that question, we conducted an "off-line" radiative forcing calculation in the GCM, using monthly mean ozone fields from the preindustrial and presentday simulations for the month of September. Percent differences between the two calculations range from less than $\pm 2 \%$ over most of the Earth to $\pm 8 \%$ in only a few grid boxes (not shown). The monthly mean, globally avcraged radiative forcing differs by less than $1 \%$. Our results suggest that synoptic-scale correlations between ozone and other radiative variables such as temperature and clouds do not significantly influence the radiative forcing from ozone and that the common use of off-line ozone fields is an acceptable method of calculating the forcing. However, it is possible that the synoptic-scale correlations cannot be adequately resolved in the model. This is an issue for further research.

To what extent does the cooling effect due to to anthropogenic sulfate aerosol offset the the warming effect 

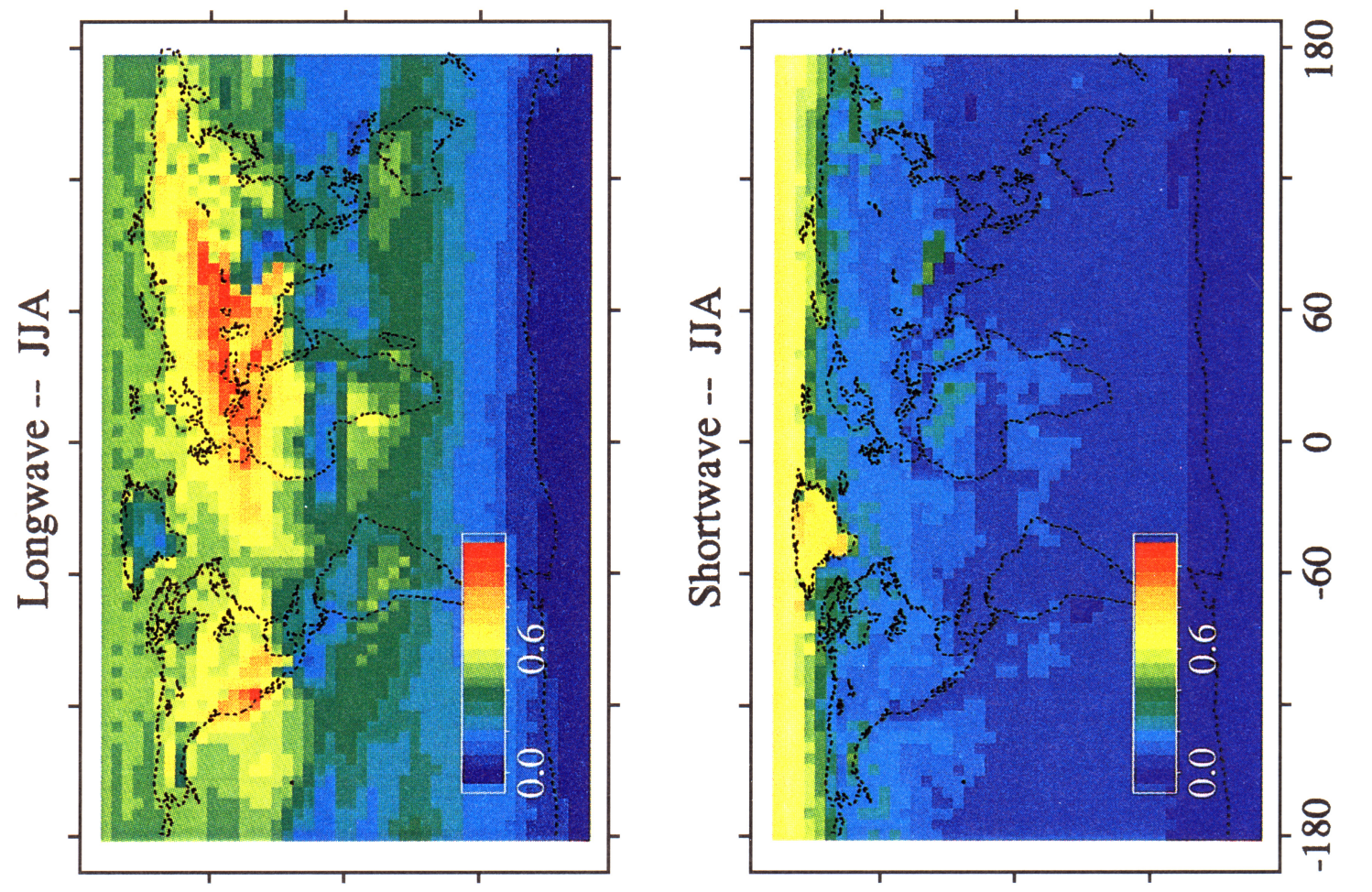

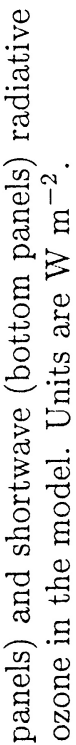
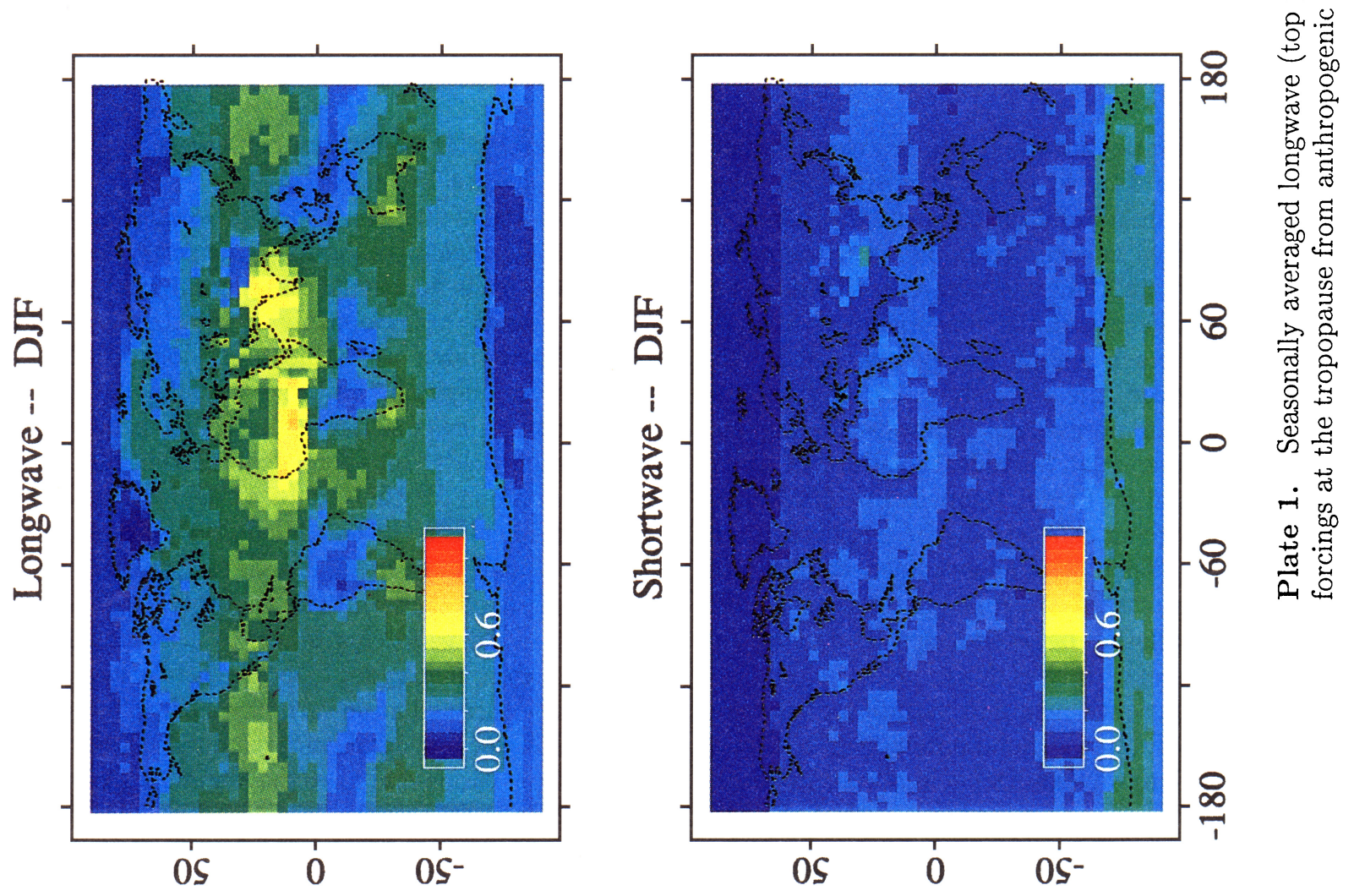


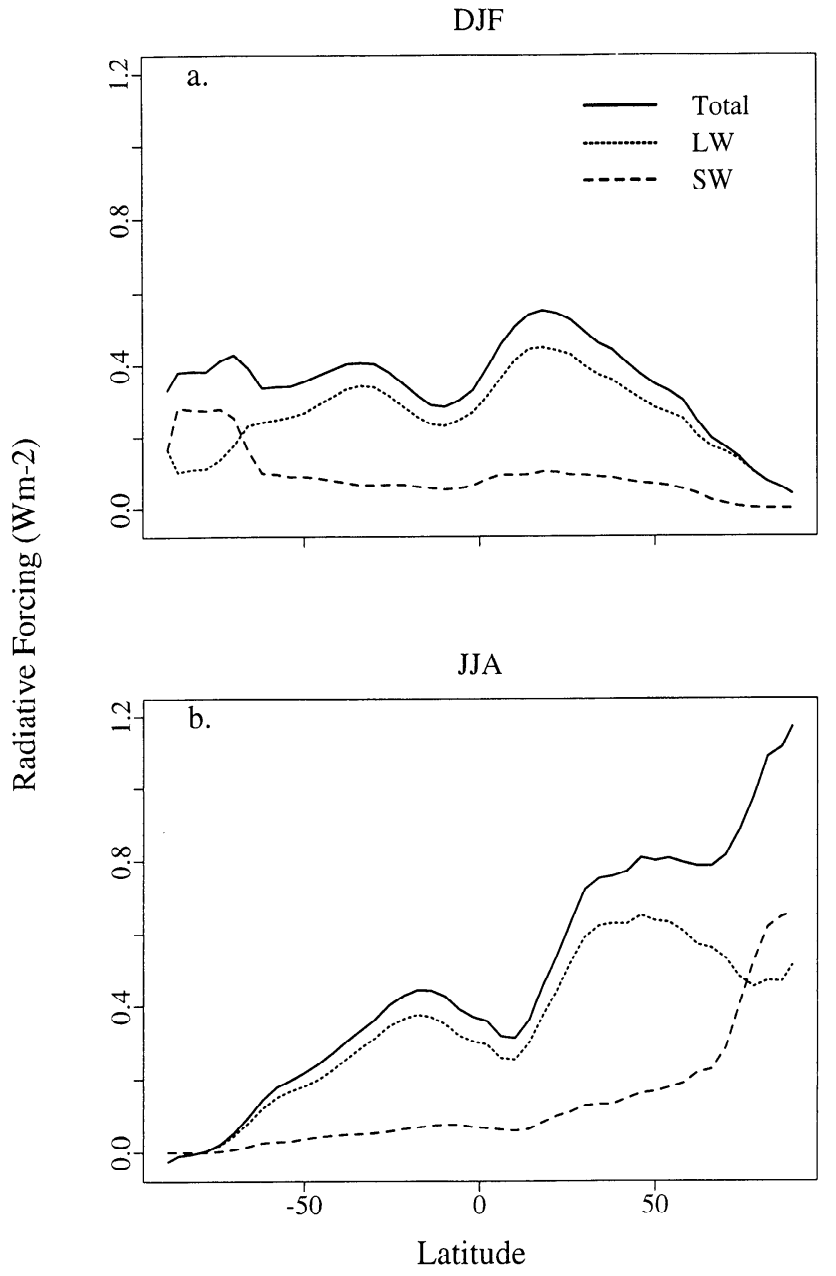

Figure 12. Zonally averaged, seasonal mean radiative forcings from anthropogenic ozone in the model for (a) December-January-February and (b) June-JulyAugust. Values are for longwave (LW), shortwave (SW), and total.

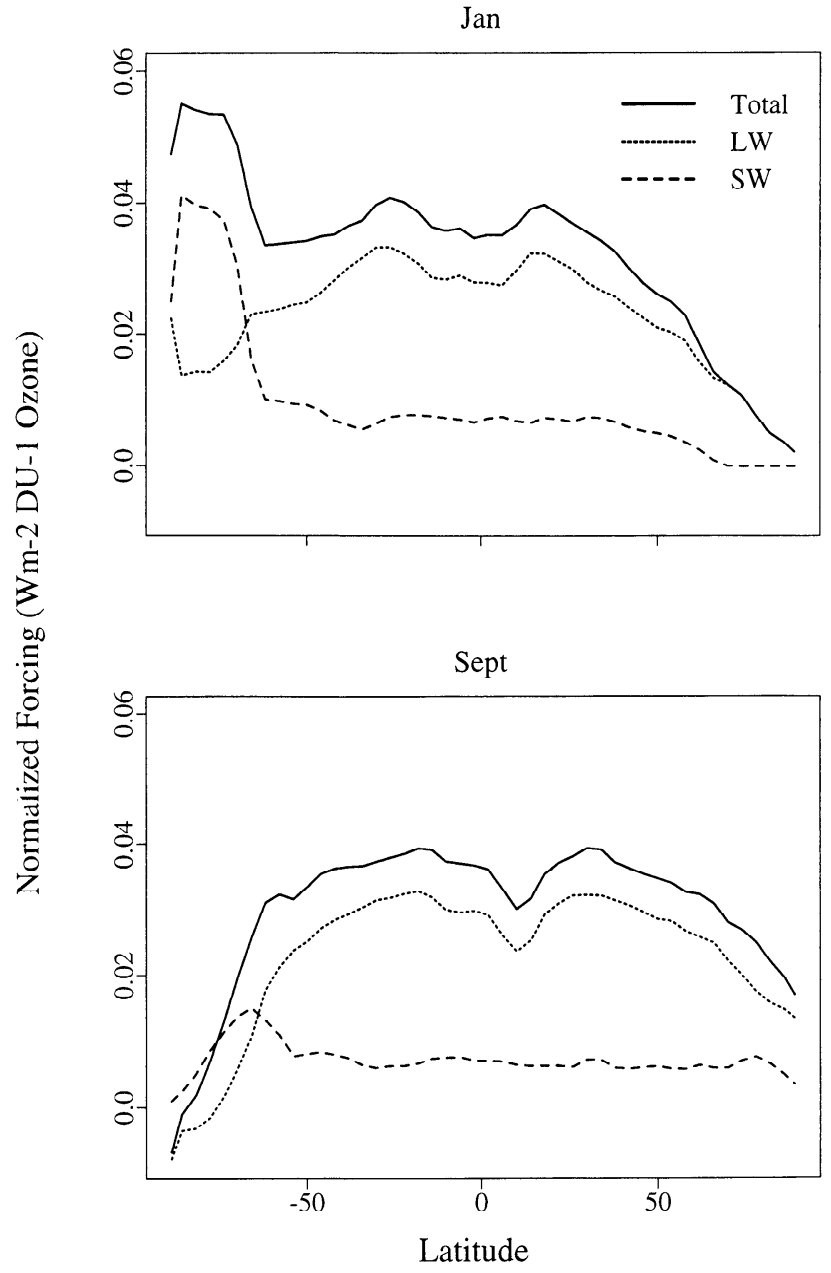

Figure 13. Zonally averaged, normalized radiative forcing $\left(\mathrm{W} \mathrm{m}^{-2} \mathrm{DU}^{-1}\right)$ from anthropogenic ozone in the model for January and September. Values are for longwave (LW), shortwave (SW), and total.

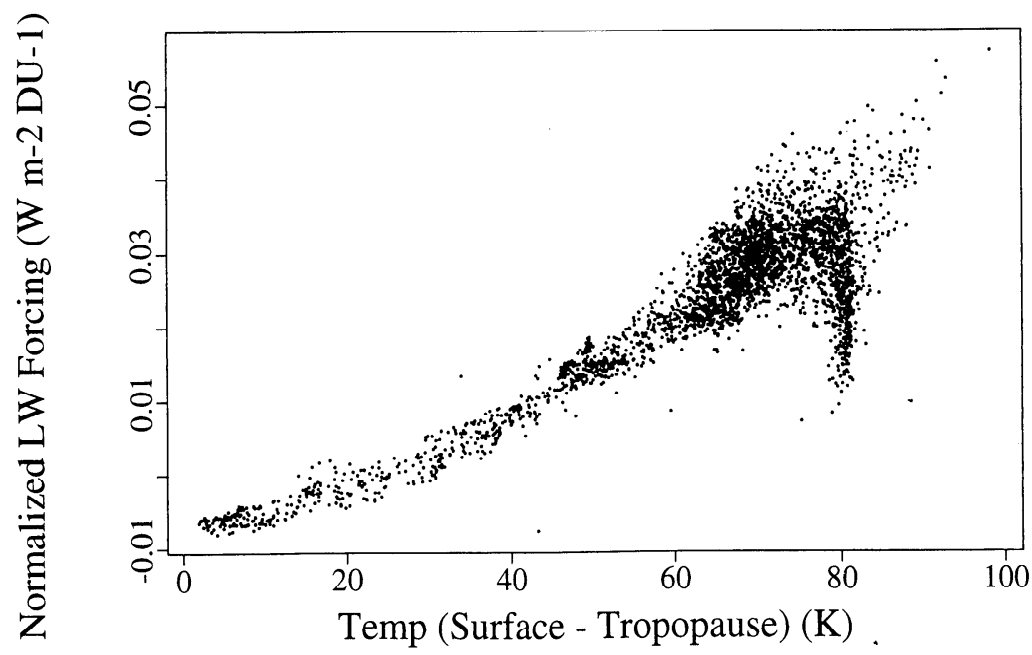

Figure 14. Normalized radiative forcing from anthropogenic ozone as a function of the monthly mean temperature difference between Earth's surface and the tropopause for each model $4^{\circ} \times 5^{\circ}$ grid square in September. 

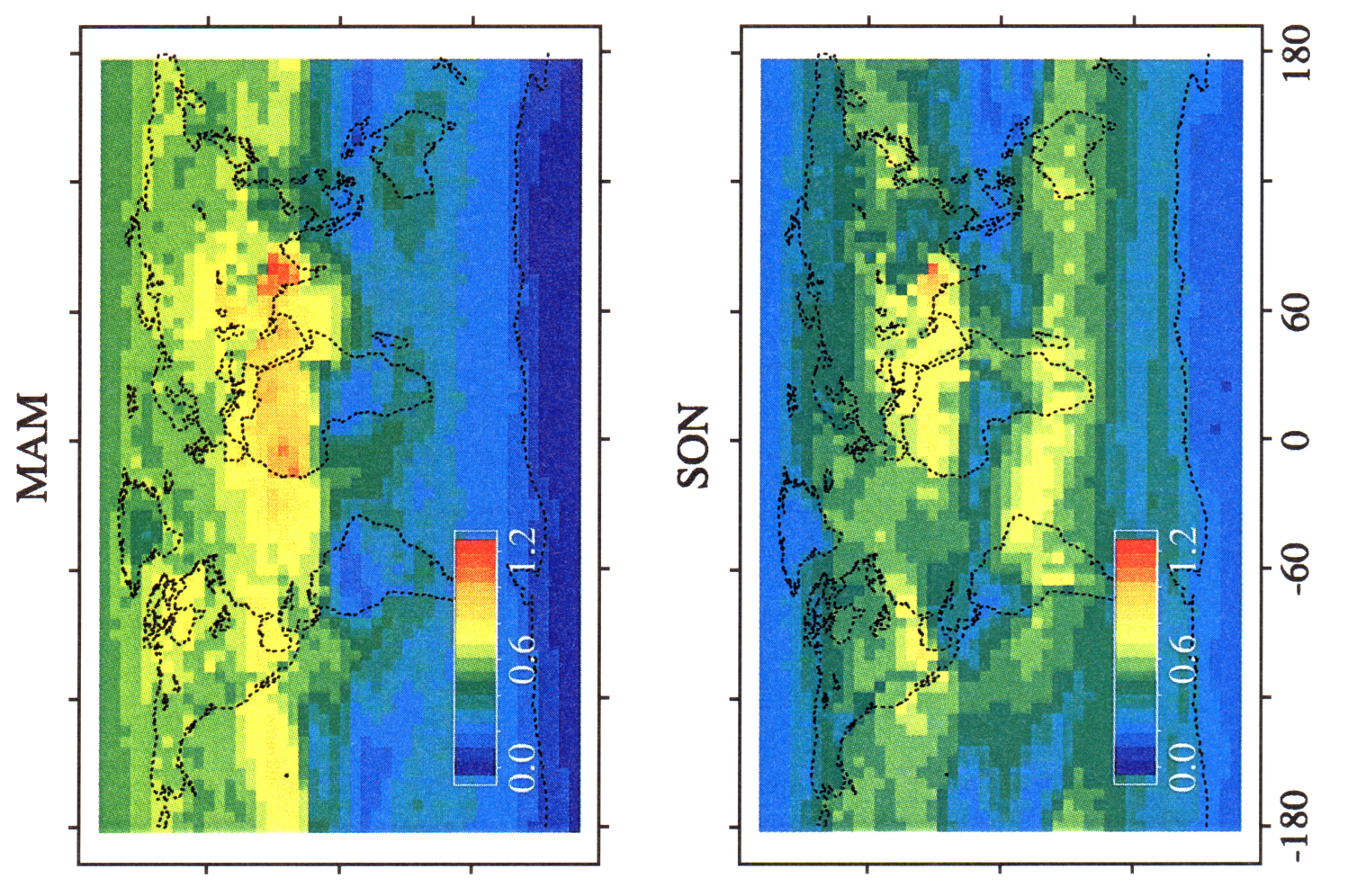

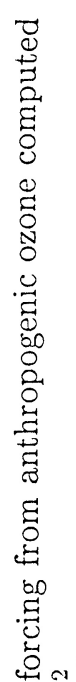
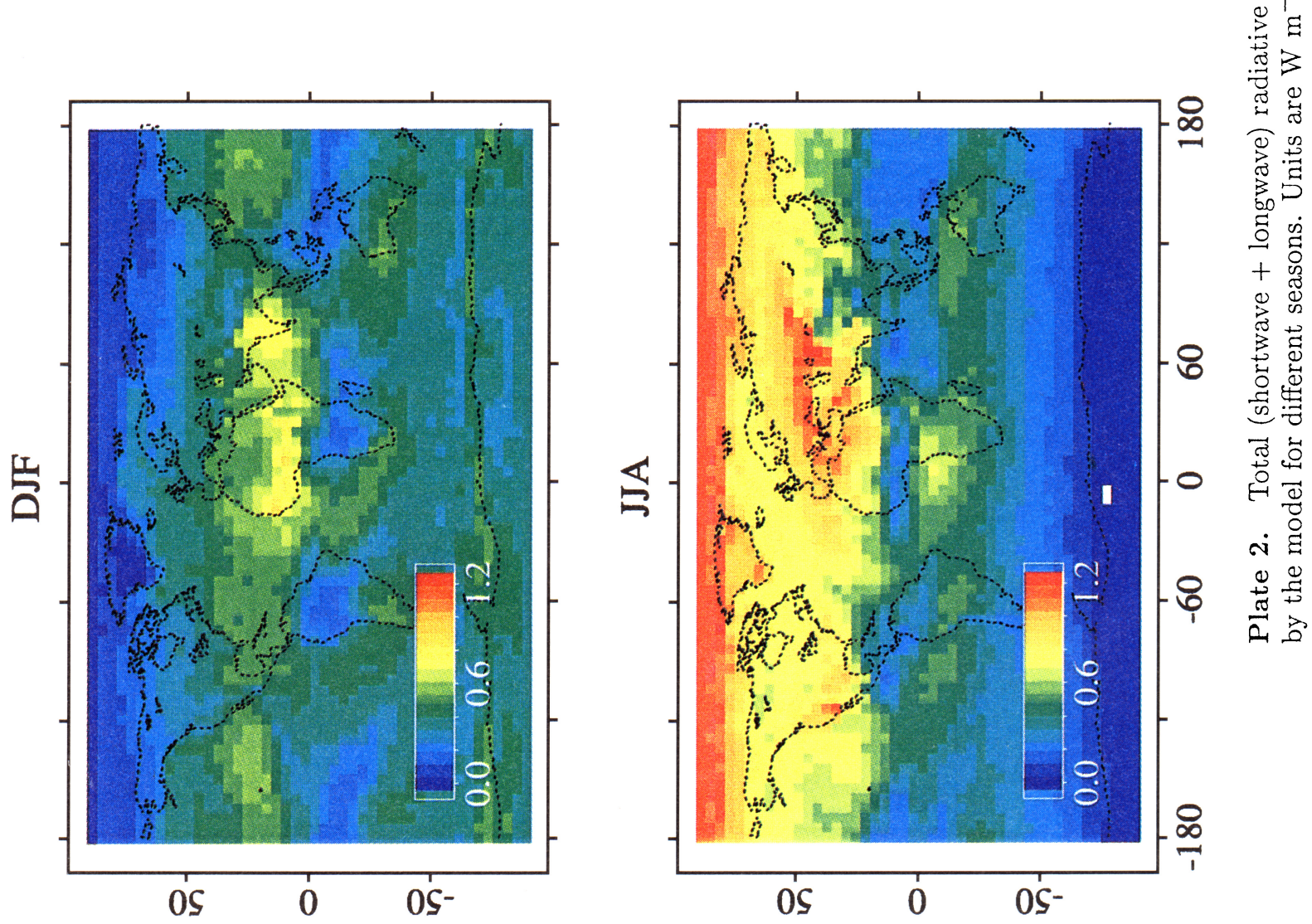


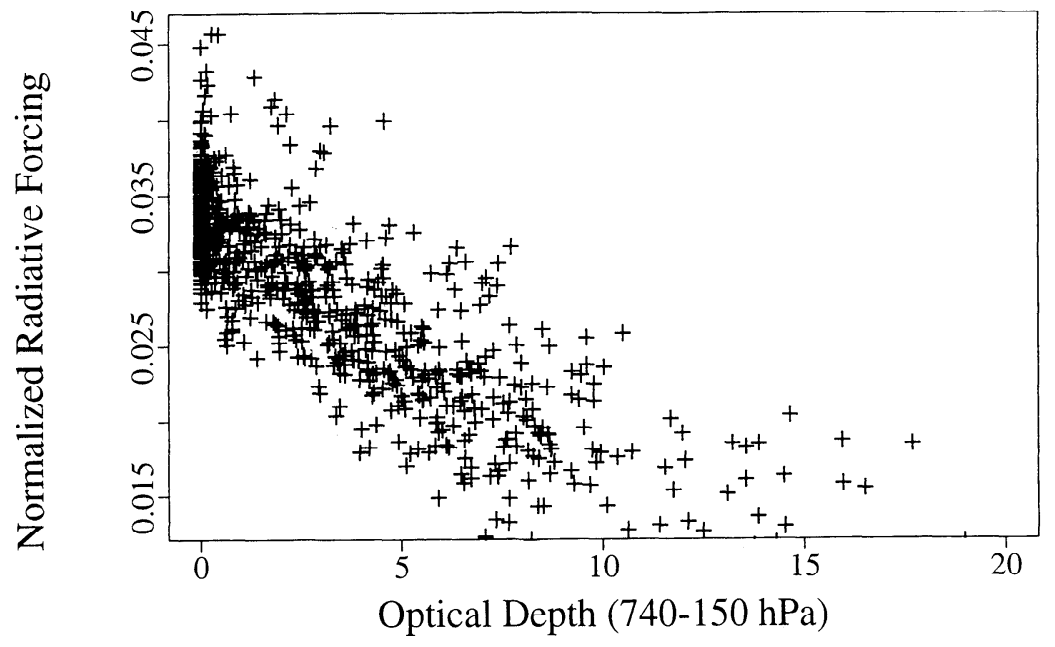

Figure 15. Normalized longwave radiative forcing as a function of monthly mean cloud optical depth between $740 \mathrm{hPa}$ and $150 \mathrm{hPa}$ for $0-20^{\circ}$ in September.

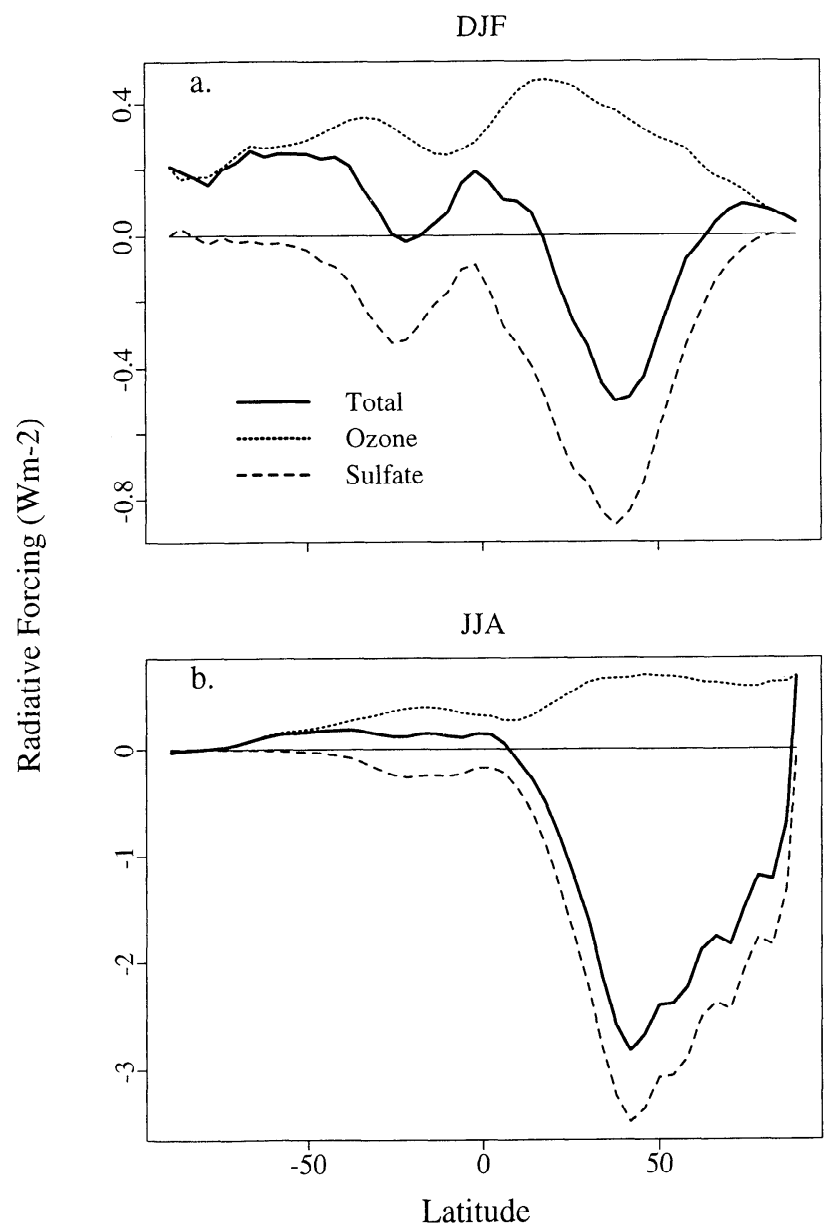

Figure 16. Zonally averaged, seasonal mean radiative forcing due to anthropogenic ozone (dotted line) and to anthropogenic sulfate aerosol (dashed line) for December-January-February and June-July-August. The thick solid line represents the sum of these two forcings. The thin line is the zero line. due to anthropogenic ozone? To answer this question, we have added the direct, instantaneous shortwave forcing from sulfate aerosol obtained by Koch et al. [1999] with the same version of the GISS GCM $2^{\prime}$ to the forcing from ozone calculated in this study. Figure 16 shows the zonally averaged radiative forcing due to ozone and to sulfate for two seasons, DJF and JJA. The effect of sulfate dominates over the Northern Hemisphere midlatitudes, particularly in summer when solar radiation is most intense and sulfate production is maximum. Ozone tends to dominate at other latitudes, reflecting the greater geographical extent of human influence on ozone than on sulfate.

The combined globally and annually averaged radiative forcing from tropospheric ozone and sulfate is -0.23 $\mathrm{W} \mathrm{m}{ }^{-2}$ (0.44 $\mathrm{W} \mathrm{m}^{-2}$ ozone, $-0.67 \mathrm{~W} \mathrm{~m}^{-2}$ sulfate). A previous study by van Dorland et al. [1997] found that the radiative forcings of sulfate and ozone nearly cancel each other, with a combined forcing of $0.02 \mathrm{~W} \mathrm{~m}^{-2}$ ( $0.38 \mathrm{~W} \mathrm{~m}^{-2}$ ozone, $-0.36 \mathrm{~W} \mathrm{~m}^{-2}$ sulfate). The sulfate negative forcing calculated by van Dorland et al. [1997] is only half that calculated by Koch et al. [1999]. One possible reason for this difference is that Koch et al. [1999] use a prognostic simulation of $\mathrm{H}_{2} \mathrm{O}_{2}$ for aqueous phase oxidation of $\mathrm{SO}_{2}$, which as they point out leads to a higher sulfate burden than off-line $\mathrm{H}_{2} \mathrm{O}_{2}$. Van Dorland et al. [1997] do not report their sulfate burden.

\section{Conclusions}

To investigate the radiative forcing due to anthropogenic ozone added to the troposphere since preindustrial times, we have implemented a detailed on-line simulation of ozone- $\mathrm{NO}_{x}$-hydrocarbon chemistry into a general circulation model, the GISS GCM 2'. Model results for ozone and related species in the presentday atmosphere compare well with observations and 
give us confidence in our use of the model as a tool to examine radiative forcing. For the preindustrial simulation, all anthropogenic emissions were shut off, except for biomass burning emissions, which were reduced to $10 \%$ of current rates. Preindustrial $\mathrm{CH}_{4}$ was 0.7 $\mathrm{ppm}$. We calculate increases in ozone since preindustrial times of $20-200 \%$ depending on region and season. The change in column ozone ranges from less than 5 DU over Antarctica to as much as 20-25 DU over industrial regions in the Northern Hemisphere during summer. Over areas affected by biomass burning pollution, the change in ozone is typically $15-20 \mathrm{DU}$.

We calculate a globally averaged radiative forcing due to anthropogenic ozone of $0.35 \mathrm{~W} \mathrm{~m}^{-2}$ in the longwave and $0.09 \mathrm{~W} \mathrm{~m}^{-2}$ in the shortwave, for a total radiative forcing of $0.44 \mathrm{~W} \mathrm{~m}^{-2}$. The radiative forcing we obtain for ozone is about one-fourth that from $\mathrm{CO}_{2}$ since preindustrial times [Houghton et al., 1995]. Ozone forcings of $0.8-1.2 \mathrm{~W} \mathrm{~m}^{-2}$ occur over the Sahara and India in spring and over large regions in the northern midlatitudes in summer. Over the Arctic in summer, particularly strong shortwave forcing results in a total forcing of more than $1.0 \mathrm{~W} \mathrm{~m}^{-2}$, comparable to the forcing at northern midlatitudes.

The normalized radiative forcing per unit of added ozone column varies globally from -0.01 to $0.05 \mathrm{~W} \mathrm{~m}^{-2}$ $\mathrm{DU}^{-1}$ in the model. At latitudes poleward of $20^{\circ}$, the variance of the normalized longwave forcing is largely determined by the temperature difference between the tropopause and Earth's surface. At lower latitudes, cloud cover is an important factor. In the shortwave, radiative forcing of ozone is amplified by high surface albedo.

To test the importance of resolving synoptic-scale correlations of ozone with other radiative variables in radiative forcing calculations, we have compared our simulation using on-line chemistry with an off-line simulation using monthly mean ozone fields as input. The two simulations generate similar forcings when averaged over the globe, as well as similar distributions of forcing. The results suggest that synoptic-scale correlations between ozone, temperature, and clouds do not significantly affect the radiative forcing from ozone and that the use of monthly mean ozone fields provides satisfactory results in radiative forcing calculations. However, further work is needed to determine if the model provides a realistic simulation of these correlations.

We examined the additive radiative forcings from tropospheric ozone and from sulfate [Koch et al., 1999] computed with the same GCM. Sulfate strongly dominates the forcings at northern midlatitudes. Ozone tends to dominate elsewhere due to the greater geographical extent of human influence. The globally and annually averaged radiative forcing due to ozone and sulfate combined is $-0.23 \mathrm{~W} \mathrm{~m}^{-2}$.

The capability for on-line simulation of the radiative forcing of tropospheric ozone provides a platform for investigation of the couplings between chemistry and climate. In the future, we plan to use the model to investigate the effects of changing climate on tropospheric ozone, methane, and aerosols, and to assess the associated chemical feedbacks such as those involving surface temperature, lightning, and ozone in the upper troposphere [Toumi et al., 1996; Sinha and Toumi, 1997].

Acknowledgments. This work was supported by the Interdisciplinary Study Program of the Earth Observing System of the National Aeronautics and Space Administration (NASA/EOS/IDS). L. Mickley acknowledges support from the National Oceanic and Atmospheric Administration (NOAA) Postdoctoral Program in Climate and Global Change and from the Bunting Institute of Radcliffe College.

\section{References}

Appenzeller, C., J. R. Holton, and K. H. Rosenlof, Seasonal variation of mass transport across the tropopause, J. Geophys. Res., 101, 15,071-15,078, 1996.

Berntsen, T. K., I. S. A. Isaksen, G. Myhre, J. S. Fuglestvedt, R. Stordal, T. A. Larsen, R. S. Freckleton, and K. P. Shine, Effects of anthropogenic emissions on tropospheric ozone and its radiative forcing, J. Geophys. Res., 102, 28,101-28,126, 1997.

Brasseur, G. P., J. Kiehl, J. F. Müller, T. Schneider, C. Granier, X. Tie, and D. Hauglustaine, Past and future changes in global tropospheric ozone: Impact on radiative forcing, Geophys. Res. Lett., 25, 3807-3810, 1998.

Brown, S. S., T. Gierczak, R. W. Portmann, R. K. Talukdar, J. B. Burkholder, and A. R. Ravishankara, Role of nitrogen oxides in the stratosphere: A reevaluation based on laboratory studies, Geophys. Res. Lett., 26, 2387-2390, 1999.

Chalita, S., D. A. Hauglustaine, H. Le Treut, and J. F. Müller, Radiative forcing due to increased tropospheric ozone concentrations, Atmos. Environ. 30, 1641-1646, 1996.

Chin, M., D. J. Jacob, G. M. Gardner, M. S. ForemanFowler, P. A. Spiro, and D. L. Savoie, A global threedimensional model of tropospheric sulfate, J. Geophys. Res., 101, 18,667-18,690, 1996.

Crutzen, P. J. and P. H. Zimmermann, The changing photochemistry of the troposphere, Tellus, 43AB, 136-151, 1991.

Del Genio, A. D., M. S. Yao, W. Kovari, and K. K. W. Lo, A prognostic cloud water parameterization for global climate models, J. Clim. 9, 270-304, 1996.

Fishman, J., C. E. Watson, J. C. Larsen, and J. A. Logan, Distribution of tropospheric ozone determined from satellite data, J. Geophys. Res., 95, 3599 3617, 1990.

Forster, P. M., C. E. Johnston, K. S. Law, J. A. Pyle, and K. P. Shine, Further estimates of radiative forcing due to tropospheric ozone changes, Geophys. Res. Lett., 23, 3321-3324, 1996.

Hansen, J., G. Russell, D. Rind, P. Stone, A. Lacis, S. Lebedeff, R. Ruedy, and L. Travis, Efficient threc-dimensional models for climate studies: Models I and II, Mon. Weather Rev., 3, 609-662, 1983.

Hansen, J., M. Sato, and R. Ruedy, Radiative forcing and climate response, J. Geophys. Res., 102, 6831-6864, 1997.

Hauglustaine, D. A., G. P. Brasseur, S. Walters, P. J. Rasch, J. F. Müller, L. K. Emmons, and M. A. Carroll, MOZART: A global chemical transport model for ozone and related chemical tracers, 2, Model results and evaluation, J. Geophys. Res., 103, 28,291-28,335, 1998.

Hauglustaine, D. A., C. Granier, G. P. Brasseur, and G. 
Mégie, The importance of atmospheric chemistry in the calculation of radiative forcing on the climate system, $J$. Geophys. Res., 99, 1173-1186, 1994.

Haywood, J. M., M. D. Schwarzkopf, and V. Ramaswamy, Estimates of radiative forcing due to modeled increases in the tropospheric ozone, J. Geophys. Res., 103, 16,99917,007, 1998.

Horowitz, L. W., and D. J. Jacob, Global impact of fossil fuel combustion on atmospheric $\mathrm{NO}_{x}, J$. Geophys. Res., 104, 23,835-23,840, 1999.

Horowitz, L. W., J. Liang, G. M. Gardner, and D. J. Jacob, Export of reactive nitrogen from North America during summertime: Sensitivity to hydrocarbon chemistry, $J$. Geophys. Res., 103, 13,451-13,476, 1998.

Houghton, J. T., et. al (Eds.), Climate Change 1994: The IPCC Scientific Assessment, Cambridge Univ. Press, New York, 1995.

Jacobson, M. Z., and R. P. Turco, SMVGEAR: A sparsematrix, vectorized GEAR code for atmospheric transport models, Atmos. Environ., 28, 273-284, 1994.

Kanakidou, M. and P. J. Crutzen, Scale problems in global tropospheric chemistry modeling: Comparison of results obtained with a three-dimensional model adopting longitudinally uniform and varying emissions of $\mathrm{NO}_{x}$ and NMHC, Chemosphere, 26, 787-801, 1993.

Kiehl, J. T., T. Schneider, R. Portmann, and S. Solomon, Climate forcing due to tropospheric and stratospheric ozone, J. Geophys. Res., in press, 1999.

Koch, D., D. Jacob, I. Tegen, D. Rind, and M. Chin, Tropospheric sulfur simulation and sulfate direct radiative forcing in the GISS GCM, J. Geophys. Res., 104, 23,799$23,822,1999$

Lacis, A. A., D. J. Wuebbles, and J. A. Logan, Radiative forcing of climate by changes in the vertical distribution of ozone, J. Geophys. Res., 95, 9971-9981, 1990.

Lawrence, M. G., and P. J. Crutzen, The impact of cloud particle gravitation settling on soluble trace gas distributions, Tellus, 50B, 263-289, 1998.

Levy, H., P. S. Kasibhatla, W. J. Moxim, A. A. Klonecki, A. I. Hirsch, S. J. Oltmans, and W. L. Chamedies, The global impact of human activity on tropospheric ozone, Geophys. Res. Lett., 24, 791-794, 1997.

Liang, J., L. W. Horowitz, D. J. Jacob, Y. Wang, A. M. Fiore, J. A. Logan, G. M. Gardner, and J. W. Munger, Seasonal budgets of reactive nitrogen species and ozone over the United States, and export fluxes to the global atmosphere .J. Geophys. Res., 10\%, 13,435-13,450, 1998.

Liu, S. C., M. Trainer, F. C. Fehsenfeld, D. D. Parrish, E. J. Williams, D. W. Fahey, G. Hübler, and P. C. Murphy, Ozone production in the rural troposphere and the implications for regional and global ozone distributions $J$. Geophys. Res., 92, 4191-4207, 1987.

Logan, J. A., An analysis of ozondesonde data for the lower stratosphere: Recommendations for testing models. $J$. Geophys. Res., 104, 16,151-16,170, 1999a.

Logan, J. A., An analysis of ozondesonde data for the troposphere: Recommendations for testing 3-D models and development of a gridded climatology for tropospheric ozone, J. Geophys. Res., 104, 16,115-16,149, 1999b.

Logan, J. A., M. J. Prather, S. C. Wofsy, and M. B. McElroy , Tropospheric chemistry: A global perspective, $J$. Geophys. Res., 86, 7210-7254, 1981.

Marenco, A., H. Gouget, P. Nédélec, J. P. Pagés, and F. Karcher, Evidence of a long-term increase in tropospheric ozone from Pic du Midi data series: Consequences: Positive radiative forcing, $J$. Geophys. Res., 99, 16,61716,632, 1994.

McKeen, S. A., T. Gierczak, J. B. Burkholder, P. O. Wennberg, T. F. Hanisco, E. R. Keim, R. S. Gao, S. C. Liu, A. R. Ravishankara, and D. W. Fahey, The photochemistry of acetone in the upper troposphere: A source of oddhydrogen radicals, Geophys. Res. Lett., 24, 3177-3180, 1997.

Novelli, P. C., K. A. Masarie, and P. M. Lang., Distributions and recent changes in carbon monoxide in the lower troposphere, J. Geophys. Res., 103, 19,015-19,033, 1998.

Oltmans, S. J., and H. Levy, Surface ozone measurements from a global network, Atmos. Fnviron. 28, 9-24, 1994.

Pickering, K. E., A. M. Thompson, J. R. Scala, W. K. Tao, R. R. Dickerson, and J. Simpson, Free tropospheric ozone production following entrainment of urban plumes into deep convection, J. Geophys. Res., 97, 17,985-18,000, 1992.

Portmann, R. W., S. Solomon, J. Fishman, J. R. Olson, J. T. Kiehl, and B. Briegleb, Radiative forcing of the Earth's climate system due to tropical tropospheric ozone production, J. Geophys. Res., 102, 9409-9417, 1997.

Prather, M., Numerical advection by conservation of secondorder moments, J. Geophys. Res., 91, 6671-6681, 1986.

Prinn, R. G., R. F. Weiss, B. R. Miller, J. Huang, F. N. Alyea, D. M. Cunnold, P. J. Fraser, D. E. Hartley, and P. G. Simmonds, Atmospheric trends and lifetime of $\mathrm{CH}_{3} \mathrm{CCl}_{3}$ and global $\mathrm{OH}$ concentrations, Science, 269, 187-192, 1995.

Rind, D., and J. Lerner, Use of on-line tracers as a diagnostic tool in general circulation model development, 1 , Horizontal and vertical transport in the troposphere, $J$. Geophys. Res., 101, 12,667-12,683, 1996.

Rind, D., J. Lerner, K. Shah, and R. Suozzo, Use of on-line tracers as a diagnostic tool in general circulation model development, 2, Transport between the troposphere and the stratosphere, J. Geophys. Res., 104, 9123-9139, 1999.

Roelofs, G. J., J. Lelieveld, and R. van Dorland, A threedimensional chemistry/general circulation model simulation of anthropogenically derived ozone in the troposphere and its radiative forcing, J. Geophys. Res., 10\%, 23,38923,401, 1997

Schultz, M. G., D. J. Jacob, J. D. Bradshaw, S. T. Sandholm, J.E. Dibb, R. W. Talbot, and H.B. Singh, Reconciliation of the $\mathrm{NO}_{x}$ budget in the upper troposphere over the tropical South Pacific, J. Geophys. Res., in press, 1999.

Sillman, S., and P. J. Samson, Impact of temperature on oxidant photochemistry in urban, polluted rural and remote enviroments, J. Geophys. Res., 100, 11,497-11,508, 1995.

Sinha, A., and R. Toumi, Tropospheric ozone, lightning, and climate change, J. Geophys. Res., 102, 10,667-10,672, 1997.

Spivakovsky, C. M., R. Yevich, J. A. Logan, S. C. Wofsy, and M. B. McElroy, Tropospheric $\mathrm{OH}$ in a three-dimensional chemical tracer model: An assessment based on observations of $\mathrm{CH}_{3} \mathrm{CCl}_{3}, J$. Geophys. Res., 95, 18441-18,471, 1990

Staehelin, J., J. Thudium, R. Buehler, A. Volz-Thomas, and W. Graber, Trends in surface ozone concentrations at Arosa (Switzerland), Atmos. Environ., 28, 75-87, 1994.

Stevenson, D. S., C. E. Johnson, W. J. Collins, R. G. Derwent, and K. P. Shine, Evolution of tropospheric ozone radiative forcing, Geophys. Res. Lett., 25, 3819-3822, 1998.

Thompson, A. M., The oxidizing capacity of the earth's atmosphere: probable past and future changes, Science, 256, 1157-1165, 1992.

Toumi, R., J. D. Haigh, and K. S. Law, A tropospheric ozone-lightning climate feedback, Geophys. Res. Lett., 23, 1037-1040, 1996.

van Dorland, R., F. J. Dentener, and J. Lelieveld, Radiative forcing due to tropospheric ozone and sulfate aerosols, $J$. Geophys. Res., 102, 28,079-28,100, 1997.

Wang, W., J. P. Pinto, and Y. L. Yung, Greenhouse effects due to man-made perturbations of trace gases, J. Almos. 
Sci., 37, 333-338, 1980.

Wang, Y., and D. J. Jacob, Anthropogenic forcing on tropospheric ozone and $\mathrm{OH}$ since preindustrial times, J. Geophys. Res., 103, 31,123-31,135, 1998.

Wang, Y., D. J. Jacob, and J. A. Logan, Global simulation of tropospheric $\mathrm{O}_{3}-\mathrm{NO}_{x}$-hydrocarbon chemistry, 3, Origin of tropospheric ozone and effects of nonmethane hydrocarbons, J. Geophys. Res., 103, 10,757-10,767, 1998a.

Wang, Y., D. J. Jacob, and J. A. Logan, Global simulation of tropospheric $\mathrm{O}_{3}-\mathrm{NO}_{x}$-hydrocarbon chemistry, 1, Model formulation, J. Geophys. Res., 103, 10,713-10,725, $1998 \mathrm{~b}$.

Wang. Y., D. J. Jacob, and J. A. Logan. Global simulation of tropospheric $\mathrm{O}_{3}-\mathrm{NO}_{x}$-hydrocarbon chemistry, 2,
Model evaluation and global ozone budget, J. Geophys. Res., 103, 10,727-10,755, 1998c.

D. J. Jacob, J. A. Logan, L. J. Mickley, and P. P. Murti, Department of Earth and Planetary Sciences and Division of Engineering and Applied Sciences Harvard University, Cambridge, MA 02138 .

D. M. Koch and D. Rind, Goddard Institute for Space Studies, 2880 Broadway, New York, NY 10025.

(Received March 26, 1999; revised June 15, 1999; accepted June 17, 1999.) 